\title{
Classified Boards, the Cost of Debt, and Firm Performance
}

Article in Journal of Banking \& Finance · August 2012

DOI: $10.2139 /$ ssrn. 1729472

CITATIONS

10

1 author:

Dong Chen

University of Baltimore

17 PUBLICATIONS 80 CITATIONS

SEE PROFILE
READS

175

All content following this page was uploaded by Dong Chen on 17 June 2014. 


\title{
Classified Boards, the Cost of Debt, and Firm Performance
}

\author{
Dong Chen $^{1}$
}

\begin{abstract}
This paper documents that classified boards substantially reduce the cost of debt. The evidence is not consistent with the argument that bondholders benefit from board classification because they are concerned about hostile takeovers. Instead, the results suggest that weak shareholder rights in the form of classified boards reduce managerial risk-taking, and the lessened concern for takeovers also increases managerial incentive for financial disclosure, with both effects inuring to bondholders' benefit. Under the circumstances that the agency conflict between shareholders and bondholders is severe, classified boards are benign to firm performance, despite their adverse impact on performance otherwise.
\end{abstract}

This draft: August 10, 2011

First draft: August 2, 2010

Keywords: classified board, corporate governance, agency cost of debt, firm performance, antitakeover, risk-taking, disclosure, transparency

JEL Classification: G30, G34

\footnotetext{
${ }^{1}$ University of Baltimore. 1420 N Charles St, Baltimore, MD 21201. dchen@ubalt.edu, (410)837-4919, (410)837$5722($ fax)

I thank Morgan Rose, Chia-Jane Wang, and two anonymous referees for helpful comments to earlier versions of the draft. I owe an enormous debt of gratitude to my advisor, Michael Bradley, for his many insightful comments. As always, all the errors are my own.
} 


\section{Introduction}

Board classification is a governance structure whereby directors are assembled into distinctive classes (typically three), with each class elected at successive annual meetings. Exempting directors from annual elections reduces shareholder rights and serves as a potent antitakeover device, since dissident shareholders have to institute at least two successful proxy fights to secure the majority control of a three-class classified board (Daines and Klausner (2001); Bebchuk, Coates and Subramanian (2002); Bates, Becher and Lemmon (2008)). ${ }^{2}$

This paper examines the effect of classified boards on the cost of debt and the implications on firm performance. Two observations motivate this study. First, prior literature that also examines the effect of antitakeover provisions on the cost of debt mainly relies on composite indexes to proxy for the antitakeover strength of a firm, such as the G-index (Klock, Mansi and Maxwell (2005); Chava, Livdan and Purnanandam (2009); Farre-Mensa (2010); Francis, Hasan, John and Waisman (2010)). ${ }^{3}$ But unlike board classification, the antitakeover effects of these indexes are primarily inferred from their adverse impact on firm performance (Gompers, Ishii and Metrick (2003); Bebchuk, Cohen and Farrell (2009)), and hence lack direct empirical support. The construction of these indexes by summing up the indicators for the presence of an antitakeover provision may "not accurately reflect the relative impacts of different provisions" (Gompers, Ishii and Metrick (2003, p114)). Recent evidence also casts doubt on the robustness of the performance effects of these indexes (Core, Guay and Rusticus (2006); Johnson, Moorman and Sorescu (2009)). Furthermore, most papers on antitakeover provisions and the cost of debt focus

\footnotetext{
${ }^{2}$ Bates, Becher, and Lemmon (2008) find that conditional on receiving a takeover bid, board classification does not reduce the ultimate likelihood of the firm to be acquired. However, they also document that board classification reduces the likelihood of becoming a takeover target. Therefore, the empirical evidence overall supports the antitakeover effect of classified boards.

${ }^{3}$ The G-index is the sum of 24 antitakeover/managerial entrenchment indicators, of which board classification is a component (Gompers, Ishii and Metrick (2003)).
} 
on the interpretation of the results through the takeover channel and ignore other potential explanations, such as managerial risk-taking and financial disclosure. I consider several hypotheses that may explain the relation between classfied boards and the cost of debt in this paper. A second motivation for this study is that although extensive research has examined the effect of classified boards on firm performance (e.g., Bebchuk and Cohen (2005); Faleye (2007); Masulis, Wang and Xie (2007); Bebchuk, Cohen and Wang (2011)), none has examined how this board structure matters for bondholders. ${ }^{4}$ The consensus finding in the literature is that board classification is associated with lower firm performance, presumably reflecting its antitakeover effect. But since a governance structure that is harmful to shareholders may not be harmful to bondholders, whether and how classified boards matter for bondholders and the cost of debt are unclear. This question is not only important by itself, but also relevant for the assessment of this governance structure from shareholders' perspective, since the cost of debt also matters for shareholders and firm performance. The negative effect of classified boards on firm performance as documented in prior literature may not hold universally, provided that classified boards reduce the cost of debt and such benefit is sufficient to balance or overcome their associated costs under some circumstances. Therefore, governance studies that exclude the consideration of bondholders may draw misleading conclusions. ${ }^{5}$

Based on a sample of S\&P 1,500 firms with publicly traded senior unsecured bonds from 2002 to 2007, I document that classified boards are strongly associated with a lower cost of debt. For the median firm in the sample, board classification reduces the bond spread by 40.6 basis points, a dramatic 22.2 percent reduction. The result is robust to the inclusion of a number of

\footnotetext{
${ }^{4}$ Jun, Jung and Walkling (2009) document that share repurchases have a more adverse effect on bondholder returns if a firm has a classified board. But the study on the general effects of classified boards on bondholders' wealth and the cost of debt is lacking to the author's best knowledge.

${ }^{5}$ See John and John (1993), John and Senbet (1998), Bradley and Chen (2011), and King and Wen (2011) for similar arguments.
} 
governance variables that the literature has shown to be relevant for the cost of debt, including the composite antitakeover indexes (the G-index, the E-index in Bebchuk, Cohen and Farrell (2009), and the ATI in Cremers, Nair and Wei (2007)). Surprisingly and inconsistent with most papers that rely on these indexes to study the effect of antitakeover provisions on the cost of debt, I show that the large effect of classified boards on the cost of debt may not be explained by the concern of bondholders for the leverage- or risk-increasing effect associated with takeovers (Klock, Mansi and Maxwell (2005); Chava, Livdan and Purnanandam (2009); Farre-Mensa (2010); Francis, Hasan, John and Waisman (2010)). Instead, I show that the weak shareholder rights associated with board classification reduce managerial risk-taking, which coincidently alleviates the risk-shifting incentive of shareholders to expropriate bondholders and reduces the agency costs of debt (henceforth ACD) (Jensen and Meckling (1976); Myers (1977)). Consistent with this idea, I document that the effect of classified boards on the cost of debt is more pronounced when firms are expected to incur higher ACD. I also find that the reduced pressure from takeovers under a classified board structure improves financial disclosure, which also benefits bondholders (Stein (1988); Duffie and Lando (2001); Fu and Liu (2008); Zhao and Chen (2008)). Since financial disclosure is more valuable to investors when they are more uncertain about the financial condition and performance of a firm (Sengupta (1998)), I show that classified boards reduce the cost of debt more under higher degree of market uncertainty. Finally, based on the notion that the reduction in the cost of debt also benefits shareholders, I analyze the effect of classified boards on firm performance. Clearly, firm performance also depends on factors other than the cost of debt such as cash flows and the cost of equity, and therefore the net effect of classified boards on performance may not be driven by the effect of classified boards on the cost of debt. Nevertheless, consistent with the significant reduction in the cost of debt under the 
circumstances characterized by strong agency conflict between shareholders and bondholders, I document a benign impact of classified boards on performance under these scenarios, despite the overall adverse performance effect of classified boards.

This paper adds to the study on the relationship between corporate governance and the cost of debt (Bhojraj and Sengupta (2003); Anderson, Mansi and Reeb (2004); Klock, Mansi and Maxwell (2005); Ortiz-Molina (2006); Cremers, Nair and Wei (2007); Chava, Livdan and Purnanandam (2009); Qiu and Yu (2009); Bradley and Chen (2010); Farre-Mensa (2010); Francis, Hasan, John and Waisman (2010); Bradley and Chen (2011)). In contrast with Qiu and $\underline{\mathrm{Yu}(2009)}$, who document that the enactment of business combination laws, a state antitakeover statute, increases the cost of debt, I find that a firm-level antitakeover provision - board classification reduces the cost of debt. This result is similar to the findings in Klock, Mansi and Maxwell (2005), Chava, Livdan and Purnanandam (2009), Farre-Mensa (2010), and Francis, Hasan, John and Waisman (2010). But unlike these authors who employ composite indexes of provisions with unproven antitakeover effect, I use an empirically-validated antitakeover proxy and document evidence that is inconsistent with their interpretation that bondholders benefit from an antitakeover provision because they are concerned about hostile takeovers. Since classified boards are one of the most important takeover defenses in the components of the antitakeover indexes, ${ }^{6}$ this result also casts doubt on the interpretation of the negative effects of these indexes on the cost of debt through the takeover channel. Interestingly, Bradley and Chen (2011) show that the provisions that limit the liability of directors and indemnify their litigation expenses (LLI provisions), which are also the components of the G-index and arguably not a strong takeover defense, are strongly associated with a lower cost of debt. Bradley and Chen

\footnotetext{
${ }^{6}$ For example, Daines and Klausner (2001) argue that the delay provisions, of which board classification is the single most important component, are the most crucial in insulating a firm from hostile takeovers.
} 
(2011) further demonstrate that after netting out the effects of LLI provisions and classified boards, the G-index becomes positively associated with the cost of debt, which casts further doubt on the robustness of the negative effect of the G-index on the cost of debt. Unlike Bradley and Chen (2011), who rest their argument on the self-serving incentives of directors with the protection of LLI provisions, I show that board classification not only encourages management to conduct low-risk corporate policies, but also promotes the financial transparency of a firm, with both effects ultimately redounding to bondholders' benefit. Related, Bhojraj and Sengupta (2003) and Anderson, Mansi and Reeb (2004) argue that more independent boards are associated with better information disclosure and hence reduce the cost of debt. I show that takeover pressure may motivate managers to obfuscate financial transparency and therefore antitakeover provision increases their incentive to disclose information and benefit bondholders.

This research also fills an important gap in the study of classified boards. I conduct the first empirical analysis of this antitakeover provision on the cost of debt, and connect the results to the extensively researched performance impact of classified boards. I document a differential effect of classified boards on firm performance conditional on the expected ACD, and show that under certain scenarios classified boards improve firm performance. These results demonstrate that "weak governance" can be beneficial for shareholders, which may have implications on the "declassification movement" - shareholder activists have pushed to repeal classified boards since the early 1990s, perhaps after the establishment of the strong antitakeover effect of this board structure (Guo, Kruse and Nohel (2008); Murti (2005)). ${ }^{7}$ The results in this paper suggest that although declassification may benefit shareholders on average (Guo, Kruse and Nohel (2008); Bebchuk, Cohen and Wang (2011)), firms may consider maintaining their classified board

\footnotetext{
${ }^{7}$ See, e.g., the survey in Georgeson (2006) on the statistics of annual shareholder proposals. Repealing a classified board has been among the most popular proposals, and has consistently won shareholder support.
} 
structure when their bondholders are most concerned about the wealth expropriation from shareholders. Although Rose (2009) and Ahn, Goyal and Shrestha (2010) also study the differential effects of classified boards on firm performance, they focus on the benefits of board classification to enhance "board stability" and facilitate the firm-specific human capital investment and information acquisition by directors. ${ }^{8}$

The remainder of the paper is organized as follows. Section 2 discusses the related literature and the potential effects of classified boards on bondholders. Section 3 describes the sample, variables, and summary statistics. Section 4 tests the empirical relation between classified boards and the cost of debt, and examines three hypotheses that may explain the results. Section 5 analyzes the differential impact of classified boards on firm performance in light of their effect on the cost of debt. Section 6 conducts several robustness checks. Finally, Section 7 concludes.

\section{Theoretical Arguments on Classified Boards and the Cost of Debt}

As a governance provision that potentially weakens shareholder rights and serves as an antitakeover device, board classification may matter for bondholders through several channels. First, antitakeover provisions are relevant for bondholders through the takeover channel, which is the focus of the discussion in the literature (Klock, Mansi and Maxwell (2005); Cremers, Nair and Wei (2007); Chava, Livdan and Purnanandam (2009); Qiu and Yu (2009); Farre-Mensa (2010); Francis, Hasan, John and Waisman (2010)). It is recognized that takeover defense may have opposing effects on the cost of debt, since takeovers may either hurt bondholders by increasing leverage or risk of target firms (Warga and Welch (1993); Ghosh and Jain (2000)), or benefit bondholders through the coinsurance effect, provided that the cash flows of the two

\footnotetext{
${ }^{8}$ Rose (2009) also discusses the benefit of the antitakeover effect of classified boards in increasing the firm-specific human capital investment of employees, executives, suppliers, and surrounding polities.
} 
merging firms are not perfectly correlated with each other (Levy and Sarnat (1970); Lewellen (1971); Higgins and Schall (1975); Billett, King and Mauer (2004)).

Classified boards may also matter for bondholders by inducing managerial incentives associated with weakened shareholder rights. Absence of shareholder discipline as afforded by board classification, managers may be discouraged from undertaking risk, in an attempt to protect their firm-specific human capital investment and private benefits from control (Bertrand and Mullainathan (2003); John, Litov and Yeung (2008); Laeven and Levine (2009); Bradley and Chen (2011)). The low-risk taking may redound to bondholders' benefit by mitigating the risk-shifting incentive of shareholders to expropriate bondholders' wealth and reducing the ACD (Jensen and Meckling (1976); Myers (1977)). However, many other managerial incentives as induced by weak shareholder rights, including shirking and extracting private benefits from control, may hurt bondholders (Chava, Kumar and Warga (2010)). Therefore, the net effect of the managerial incentives associated with classified boards on bondholders is also uncertain.

An antitakeover provision may further matter for bondholders by affecting the financial disclosure and information transparency of a firm. Duffie and Lando (2001) theorize that bond investors on the secondary market with imperfect information demand a "transparency spread" for the increased default risk associated with their inability to observe the true value of the firm. Consistent with their argument, Sengupta (1998) and Yu (2005) find that firms with better disclosure quality enjoy a lower cost of debt. Though better financial transparency may help reduce the cost of debt, the effect of an antitakeover provision on financial disclosure is uncertain. On the one hand, takeover pressure is likely to increase the incentive of management to boost current profits to fend off potential acquirers by manipulating accounting and disclosure policies at the expense of long-term firm value (Stein (1988)). The survey evidence in Graham, 
Harvey and Rajgopal (2005) also shows that $78 \%$ of the sample managers sacrifice long-term value to smooth earnings under the pressure to meet earnings targets. These arguments and evidence suggest that antitakeover provisions such as board classification may improve the financial transparency of a firm. Several recent papers document evidence that is consistent with this prediction (Fu and Liu (2008); Zhao and Chen (2008); Zhao, Chen and Yao (2009)). On the other hand, White and Lublin (2007) report that managers cut back their perks after the requirement for additional disclosure on executive compensation and perquisites took effect in 2006. Therefore, undisciplined managers may obfuscate financial disclosure to protect their private benefits from control. Consistent with this argument, Kedia and Philippon (2009) document that classified boards are positively associated with the incidence of accounting restatements, which are often the result of inadequate or fraudulent financial disclosure.

Given the uncertain impact of classified boards on bondholders through the three channels as discussed above, the effect of board classification on the cost of debt is ultimately an empirical question. In Section 4 I first test the empirical relation between classified boards and the cost of debt. I then examine three hypotheses that may explain this relation, based on the three channels as discussed above. It is possible that the effect of board classification on the cost of debt comes through multiple channels. Therefore, the three hypotheses I examine in Section 4 are not mutually exclusive.

\section{Sample, Variables, and Summary Statistics}

\subsection{Data and Sample}

I assemble multiple databases in constructing the samples used in the empirical analysis. The bond data are from a proprietary database of $\mathrm{S} \& \mathrm{P}$ covering the pricing and issue characteristics 
of all rated and publicly traded senior unsecured bonds of U.S. corporations. ${ }^{9}$ The database covers the transaction prices, issuance date, maturity date, coupon payment information, and S\&P ratings. The database does not include information on other issue characteristics such as bond callability, convertibility, sinking fund provisions, etc. But there is no a-priori reason to suspect any significant omitted variable bias. I further address this issue in the robustness checks. The time coverage of the database is at the end of March from 2002 to $2007 .{ }^{10}$ Therefore, my final samples are restricted to these years. This also suggests that the sample in this paper is more recent than most papers on corporate governance and the cost of debt, which typically cover years before 2000 .

Data for classified boards and the components of the G-index are from RiskMetrics Governance Database, which covers S\&P 1,500 firms roughly biennially from 1990 to 2006 . I follow Gompers, Ishii and Metrick (2003) and assume that the data for the years not covered by RiskMetrics are the same as the data in the previous year.

Other data sources include RiskMetrics Director Database, COMPUSTAT, CRSP, EXECUCOMP, Thomson Reuters 13f Database, I/B/E/S, Thomson One Banker (for data on takeover targets), and Mergent FISD database (for covenants data).

In merging these databases, I ensure that most of the independent variables in the cost of debt regressions are observed before the bond data to alleviate the concerns with endogeneity. For example, year $t$ bond data are merged with year $t-1$ data from COMPUSTAT. I delete firms with dual-class stocks, since these firms' voting structure may imply a minimal role for other

\footnotetext{
${ }^{9}$ The inclusion of only senior unsecured bonds is the result of data limitations, but the analysis based on this sample should still have general implications. As shown in Chava, Kumar, and Warga (2010), senior unsecured bonds represent the lion's share of all outstanding bonds. In addition, these bondholders may be more concerned about governance mechanisms since, compared with secured bondholders, firms do not have collaterals pledged against their claims.

${ }^{10}$ This is so since most firms end their fiscal years in December. Therefore, having the bond spreads (the dependent variable) at the end of the first quarter makes sure that for most firms financial variables occur before bond pricing data, which may alleviate the endogeneity concerns.
} 
governance mechanisms. I also delete finance (one-digit SIC code "6") and utility firms (twodigit SIC code "49"), due to the different nature of corporate governance for these regulated industries. After merging different data sources, my final example to run the cost of debt regressions has 1,467 firm-year observations from 2002 to 2007, and 389 unique firms. Sample sizes for other regressions vary depending on model specifications.

\subsection{Variables}

In this subsection I describe the major variables used in the empirical analysis. The detailed definition for each variable is presented in the Appendix.

\subsubsection{Cost of Debt}

Following the convention in the literature, I use bond spreads to measure the cost of debt. I first calculate the yield-to-maturity (YTM) of each bond from its price and issue characteristics. I then obtain one-month, three-month, six-month, one-year, two-year, three-year, five-year, sevenyear, 10-year, 20-year, and 30-year constant maturity YTM of Treasury bonds from the Federal Reserve's H-15 release. The YTM of the Treasury bond matched by closest maturity is then subtracted from a bond's YTM to arrive at the spread of the bond. ${ }^{11}$

I also calculate the duration and convexity of each issue, since they represent the systematic risk of bond returns. I use the bond age to proxy for its liquidity. Older bonds are expected to have higher spreads than younger bonds, ceteris paribus, as older bonds are generally less liquid. Since the empirical analysis mainly relies on firm-level regressions, I follow the literature and calculate the weighted averages of the issue-level values to obtain the firm-level yield spread, duration, convexity, and bond age. The weight for each bond is its issue size as a fraction of the total issue amounts of all the outstanding bonds in the sample for the firm in a given year.

\footnotetext{
${ }^{11}$ In unreported robustness checks, I also interpolate the YTM of the Treasury bond into a piecewise linear term structure. Results are similar using the bond spread calculated from the difference between the YTM of a bond in my sample and the YTM of Treasury bond with identical maturity derived from this piecewise linear yield curve.
} 
I define a dummy variable (Cboard) that equals one if the firm has a classified board structure, and zero otherwise. Since the G-index, a commonly employed antitakeover/managerial entrenchment index, includes board classification as one of its components, I also calculate the Net G-index by subtracting the classified board dummy from the G-index.

Following the literature, financial controls for the cost of debt regressions include return on asset (ROA), firm size as proxied by the log of market capitalization, leverage, equity volatility, market-to-book ratio, and a dummy variable indicating whether the firm has subordinated debt (Bhojraj and Sengupta (2003); Anderson, Mansi and Reeb (2004); Klock, Mansi and Maxwell (2005); Ashbaugh-Skaife, Collins and LaFond (2006); Cremers, Nair and Wei (2007); Qiu and Yu (2009)). The latter two variables are expected to be positively associated with the cost of debt, since a growth firm, or a firm with subordinated debt is expected to be riskier.

I also control for a number of governance variables other than the G-index based on the literature, including the L-index which is the sum of the three indicators for the LLI provisions, CEO option and share holdings, board size and independence, and institutional and block holdings (Bhojraj and Sengupta (2003); Anderson, Mansi and Reeb (2004); Ecker, Francis, Kim, Olsson and Schipper (2006); Ortiz-Molina (2006); Bradley and Chen (2011)).

I also control for credit ratings. I create a rating variable, SP_rate, from the S\&P long-term domestic issuer credit rating, which ranges from 1 (debt in default) to 22 (AAA). According to this scheme, the lowest investment-grade bond (BBB-) is assigned a value of 13 . Thus, bonds with a rating of 12 or less are considered speculative by S\&P. It is important to note here that this rating represents the overall creditworthiness of a firm, not specific to any type of bonds. ${ }^{12}$

\footnotetext{
${ }^{12}$ According to COMPUSTAT manual, the long-term domestic issuer credit rating (data280) prior to 1998 refers to the issuer senior debt rating assigned by S\&P. Post 1998, it is an opinion of an issuer's overall creditworthiness assessed by S\&P, apart from its ability to repay individual obligations. Therefore, within the sample period used in this study, the S\&P credit rating represents the creditworthiness of the firm.
} 
Therefore, in Section 4 I use SP_rate as a proxy for the credit condition of a firm. I control for rating dummies in the regressions to account for the nonlinear relation between ratings and bond spreads. To reduce the number of variables, I follow Ashbaugh-Skaife, Collins and LaFond (2006) and collapse SP_rate into 7 categories. Rating dummies are based on these 7 categories. ${ }^{13}$

\subsubsection{Firm Performance}

Following the convention in the literature, I use Tobin's Q as a measure of firm performance. In addition to the classified board dummy and the Net G-index, other control variables include ROA, firm size as measured by the log of total assets, capital expenditure, leverage, firm age, the number of business segments, CEO share holdings, CEO tenure, and board size and independence (Yermack (1996); Bebchuk and Cohen (2005); Faleye (2007); Ahn, Goyal and Shrestha (2010)). I also control for CEO power, which is proxied by whether the CEO started to manage the company on or before its IPO, ${ }^{14}$ whether he/she is the only insider on the board, and whether he/she also serves as the chairman of the board (Adams, Almeida and Ferreira (2005)).

\subsection{Summary Statistics}

Panel A of Table 1 presents the summary statistics of the major variables in the empirical analyses. Except for the bond-related variables, the summary statistics for other variables are presented in their unrestricted format, i.e., by only requiring the availability of the data for those variables. This takes into account that many of these variables are used in different models with varying sample sizes. The statistics suggest that sixty percent of the firms in the sample have classified boards, which is consistent with other studies (e.g., Bebchuk and Cohen (2005); Bates, Becher and Lemmon (2008)). The median bond spread is $1.83 \%$ and higher than the values reported in Klock, Mansi and Maxwell (2005) and Qiu and Yu (2009) based on earlier years. The

\footnotetext{
${ }^{13}$ Results using the rating dummies based on the original S\&P rating variable without collapsing are similar.

${ }^{14}$ I use this variable to approximate the variable in Adams, Almeida and Ferreira (2005) for whether the CEO is the founder of a firm, due to my lack of the data for CEO founders.
} 
median SP_rate is 13, suggesting that the median firm in the sample is rated "BBB-", the lowestrated investment grade. The mean and median Tobin's $\mathrm{Q}$ are 1.95 and 1.59, respectively.

In Panel B I examine the change of classified boards during the sample period. Two observations can be made. First, the overall incidence of classified boards had remained quite stable. Between 2002 and 2007, less than $3.8 \%$ of the boards each year changed their classification status. ${ }^{15}$ Therefore, consistent with the accounts in the literature (e.g., Bebchuk and Cohen (2005)), most classified boards of public companies were adopted in the 1980s during the height of hostile takeovers, and changed little afterwards. The stability of the incidence of classified boards may alleviate the concerns for endogeneity, in particular reverse causality, since it is unlikely that managers respond to changing corporate environment by classifying their boards (Bebchuk and Cohen (2005); Masulis, Wang and Xie (2007); Bates, Becher and Lemmon (2008); Ahn, Goyal and Shrestha (2010)). I further address the endogeneity issue in the robustness checks. The second observation from the data is that in recent years, significantly more firms repealed their classified boards as compared with earlier periods. Between 2005 and 2007, 39 firms declassified their boards, as compared with 7 firms between 2002 and 2003. These data accord with those reported in the media (e.g., Murti (2005)) and academic studies that more firms have adopted shareholder proposals to repeal their classified boards in recent years, suggesting the increasing power of shareholders (Thomas and Cotter (2007); Guo, Kruse and Nohel (2008); Ertimur, Ferri and Stubben (2010)).

\section{Insert Table 1 about here}

Panel C reports the correlations between the major variables. Classified boards and the Net Gindex are positively and significantly correlated with each other (coefficient $=0.31$ ), consistent

\footnotetext{
${ }^{15}$ The stability of the incidence of classified boards also holds for earlier years. Between 1990 and 2002, less than $3.3 \%$ of the firms in the RiskMetrics database changed their classification status each year.
} 
with the evidence in the literature that the components of the G-index often cluster (Gompers, Ishii and Metrick (2003)). To rule out the possibility that the effects of classified boards are driven by other components of the G-index, I control for the Net G-index throughout the paper.

\section{Classified Boards and the Cost of Debt}

In this section I first examine the empirical relation between classified boards and the cost of debt. I then test three non-mutually exclusive hypotheses that may explain this relation based on the three channels I discussed in Section 2. I include Fama-French 48-industry and year dummies throughout the models. The standard errors are adjusted for heteroskedasticity (White (1980)) and clustered at the firm level to control for auto-correlations (Petersen (2009)).

\subsection{Classified Boards and the Cost of Debt}

I run pooled OLS regressions to examine the effect of classified boards on bond spreads. Table 2 reports the results. Model 1 includes classified boards, issue characteristics, and financial controls. The coefficient on classified boards is negative and significant at the $5 \%$ level. The magnitude of the coefficient, -0.406 , suggests that board classification is associated with 40.6 basis points reduction in bond spreads, which stands for a whopping $22.2 \%$ reduction for the median firm in the sample (spread=1.83). Therefore, classified boards are strongly associated with a lower cost of debt both statistically and economically. Compared with composite antitakeover indexes, classified boards have a much larger effect on the cost of debt. For example, the results in Klock, Mansi and Maxwell (2005) (Model 1 of Table 3) suggest that adding one provision to the G-index decreases bond spreads by 4.1 basis points, which is around $2.9 \%$ of the bond spread for the median firm in their sample. While an interpretation for these results which would be consistent with the arguments in prior literature (Klock, Mansi and Maxwell (2005); Cremers, Nair and Wei (2007); Chava, Livdan and Purnanandam (2009); 
Francis, Hasan, John and Waisman (2010)) is that board classification is a "cleaner" antitakeover proxy as compared with composite antitakeover indexes, and bondholders are concerned about the leverage- or risk-increasing effect of takeovers, I show in the next subsection that the evidence is not consistent with this interpretation.

The issue characteristics and financial controls generally have their expected signs, except for market-to-book ratio and the subordinated debt dummy. Though predicted to be positively associated with bond spreads, the coefficients on these two variables are negative.

\section{Insert Table 2 about here}

Since the components of the G-index often cluster as shown in Table 1, the effect of classified boards on bond spreads could be driven by other provisions in the G-index. Therefore, I control for the Net G-index in Model 2 to examine this possibility. The results suggest that the Net Gindex is negative but not significant. ${ }^{16}$ The coefficient on classified boards and its significance are intact. These results indicate that the negative effect of classified boards on the cost of debt is robust to the inclusion of other potential antitakeover provisions.

In undocumented analysis, I further test the robustness of the results on classified boards and the cost of debt, by controlling for the E-index, a refined proxy based on some components of the G-index as developed by Bebchuk, Cohen and Farrell (2009), and the ATI, another antitakeover index in Cremers, Nair and Wei (2007). ${ }^{17}$ Both indexes include classified boards as a component. The results are similar: classified boards are negative and significant throughout, and both net indexes without the classified board dummy are negative but insignificant. If controlled for alone, the ATI is negative and weakly significant at the $10 \%$ level, which is consistent with

\footnotetext{
${ }^{16}$ In untabulated analysis, I also include the G-index without the classified board dummy in the regression. The Gindex is negative but not significant, which is inconsistent with the previous findings based on earlier samples.

${ }^{17}$ To be consistent with the interpretation that a larger value of an index indicates stronger antitakeover effect, I have subtracted the ATI in Cremers, Nair, and Wei (2007) from 4 to arrive at the ATI in this paper. The original ATI in their paper proxies for the takeover vulnerability of a firm.
} 
the findings in Cremers, Nair and Wei (2007). This result is interesting since unlike the G-index and the E-index, Cremers, Nair and Wei (2007) construct their ATI based on empirical evidence in support of the antitakeover effect of its components. The robust effect of classified boards on the cost of debt with the inclusion of the ATI suggests that the effect of ATI on the cost of debt is driven by classified boards. Since I show later in this paper that classified boards' reduction in the cost of debt is unlikely due to their antitakeover effect, it also casts doubt on the interpretation of the effect of ATI on the cost of debt through the takeover channel.

The results in Model 2 suggest the different effects of the components of the G-index on the cost of debt. In Model 3, I further control for the L-index, which consists of three components of the G-index on director liability limitation and indemnification (LLI) provisions (Bradley and Chen (2011)). Consistent with Bradley and Chen (2011), L-index is negative and significant at the $5 \%$ level. The effect of classified boards on bond spreads becomes even stronger $(-0.485)$, and is larger than the effect of the L-index. In unreported F-test, however, the difference between the two effects is significant only at the $12 \%$ level. Interestingly, after controlling for the Lindex, the Net G-index becomes positive but insignificant.

In Model 4 I further control for other governance variables that the literature has found to be related to the cost of debt, including CEO option and share holdings, board size and independence, and institutional and block holdings. Consistent with Bhojraj and Sengupta (2003), institutional ownership (block holding) is negatively (positively) associated with the cost of debt. Inconsistent with Ortiz-Molina (2006) but consistent with Bradley and Chen (2011), CEO option holdings are negatively associated with bond spreads. Other governance variables are not significant. Classified boards continue to be highly significant. This result suggests that 
the effect of classified boards on the cost of debt is above and beyond the effects of other governance variables on the cost of debt.

Finally, in Model 5, I include the rating dummies. The magnitude of classified boards is smaller as compared to Model 4, which suggests that part of the beneficial effect of classified boards on a firm's bondholders is captured by the firm's credit rating as assessed by rating agencies. But the coefficient on classified boards is still about the same as that of Model 1. More interestingly, with the inclusion of the rating dummies, the Net G-index becomes positive and significant at the $10 \%$ level. This result suggests that other components of the G-index have opposite effect on the cost of debt as compared with classified boards and LLI provisions, which may explain the much smaller effect of the G-index on the cost of debt as compared with classified boards and LLI provisions. In other words, the G-index is a noisy proxy for the strength of antitakeover/managerial entrenchment, despite the wide use of this proxy. With the

additional controls, the adjusted $\mathrm{R}^{2}$ also increases from 0.37 in Model 1 to 0.42 in Model 5 . Unless otherwise noted, I use the specification in Model 5 in subsequent analysis.

Overall, the results presented in Table 2 suggest that classified boards are strongly associated with a lower cost of debt. In the following three subsections I test three hypotheses that may explain this result. These hypotheses are based on the three channels through which board classification may reduce the cost of debt as discussed in Section 2.

\subsection{Antitakeover Hypothesis}

One potential explanation for the negative effect of classified boards on the cost of debt, as also argued by many others, is that an antitakeover provision reduces the cost of debt because bondholders are concerned about leverage- or risk-increase associated with takeovers (Klock, Mansi and Maxwell (2005); Cremers, Nair and Wei (2007); Chava, Livdan and Purnanandam 
(2009); Farre-Mensa (2010); Francis, Hasan, John and Waisman (2010)). I examine this "antitakeover hypothesis" in this subsection.

Since a classified board combined with a poison pill is a far more potent antitakeover device than the classified board alone (Bebchuk and Cohen (2005)), the reduction in the cost of debt should be greater for a firm with both a classified board and a poison pill than a firm with only a classified board, if the antitakeover hypothesis holds. To test this, I interact the classified board dummy with a dummy indicating whether the firm has a poison pill in the cost of debt regression. I expect this interaction term to be negative and significant based on the arguments above. The results are reported in Model 1 of Table 3. While this interaction term is negative, it is not significant. Classified board dummy remains significant though only at the $10 \%$ level. ${ }^{18}$

\section{Insert Table 3 about here}

The above test suffers from the concerns that even if a firm may not have a poison pill before the announcement of a takeover, management can readily install one upon short notice (Ryngaert (1988)). Therefore, the incidence of poison pills in the sample does not necessarily describe the availability of this tool management has at its disposal in defending a hostile takeover. I conduct a battery of additional tests to further examine the antitakeover hypothesis.

If classified boards benefit bondholders through their antitakeover effect, one would expect the effect of board classification on the cost of debt to be stronger if a firm is subject to a higher risk of being a takeover target. As argued by Palepu (1986), predicting the acquisition likelihood is difficult, however. To get around the complications associated with this difficulty, I use the actual acquisitions to infer the ex-ante risk of a firm to be acquired. In essence, this strategy is similar to the methodologies adopted by many asset pricing papers, in which the realized return

\footnotetext{
${ }^{18}$ The reduced significance may be a result of multicollinearity - the correlation between Cboard and Cboard * Poison pill is 0.70 .
} 
is used as a proxy for the expected return. Specifically, I create a dummy variable that equals one if a firm was a takeover target between 2002 and 2007 (Target). If the ex-ante risk of being acquired is also higher for the acquisition targets, I expect classified boards to have a stronger effect on the cost of debt for these firms. To test this, I interact the Cboard dummy with the Target dummy in Model 2. ${ }^{19}$ I expect this interaction term to be negative and significant. Inconsistent with this prediction, however, Cboard * Target is positive and insignificant.

Concerned with the potential wealth expropriation by shareholders and management, bondholders often put restrictive covenants into the indenture agreements (Smith and Warner (1979); Chava, Kumar and Warga (2010)). Cremers, Nair and Wei (2007) show that if a bond includes event risk covenants (ERCs), a type of covenants that can protect bondholders during takeovers, the adverse effect of takeover vulnerability on bond spreads is attenuated. ${ }^{20}$ Therefore, if the antitakeover hypothesis holds, it is expected that bondholders with ERCs in their indentures would not value a classified board as much as bondholders who do not have ERCs. To test this, I create a variable that stands for the strength of ERC protection at the firm level (Protection). I obtain the data on ERCs from the Mergent FISD database. As a result, sample size shrinks to 1,091 firm-years. Similar to the construction of firm-level bond spreads, I calculate Protection as the weighted average of dummy variables indicating the availability of any ERCs for an issue as defined by Cremers, Nair and Wei (2007). ${ }^{21}$ I then interact this variable with Cboard in Model 3. The antitakeover hypothesis would predict this interaction term to be

\footnotetext{
${ }^{19}$ Out of the 389 firms in the sample, there were 79 acquisition targets between 2002 and 2007.

${ }^{20}$ A typical ERC is poison put, which allows bondholders of a target firm to sell their bonds back to the firm during a hostile takeover event.

${ }^{21}$ In undocumented analysis, I also calculate alternative measures of ERC protection at the firm level to check the robustness of the results. In one version, I define Protection as a dummy variable that equals one if the weighted average of dummy variables indicating the availability of ERCs at the issue level is above the sample median, and zero otherwise. In another version, Protection is defined as a dummy variable that equals one if any bond issue of the firm contains any ERCs. Finally, I define Protection as the simple average of the dummy variables indicating the incidence of ERCs at the issue level. Results based on the interactions of these alternative measures of ERC protection at the firm level with classified boards are all similar: none of the interaction terms is significant.
} 
positive and significant. Since Bradley and Roberts (2004) show that covenants may reduce bond yields, I also control for Protection in the model. Inconsistent with the antitakeover hypothesis, however, Protection * Cboard is negative and insignificant. Perhaps as a result of the smaller sample size, the significance of classified boards also diminishes, but the magnitude remains the same. These results imply that regardless of the strength of ERCs, bondholders are equally benefited from classified boards, which suggests that the beneficial effect of classified boards on bondholders may not come through the takeover channel.

Shastri (1990) argues that takeovers may have a differential impact on bondholders' wealth depending on firm and issue characteristics of the target versus the acquirer. Specifically, the detrimental leverage- or risk-increasing effect of takeovers on target bondholders would be more pronounced if the leverage (risk) of the target firm is low relative to the acquirer, since the likelihood of the combined firm to have a higher leverage (risk) is high. The evidence in Billett, King and Mauer (2004) supports these arguments. Therefore, if the antitakeover hypothesis holds, bondholders of firms with low leverage or high credit rating (a proxy for default risk) should be more concerned about takeovers, and therefore classified boards should benefit these bondholders more. I examine these predictions in the next subsection, where I test the "risktaking hypothesis", which is based on the argument that board classification may mitigate the risk-shifting incentive of shareholders to expropriate bondholders' wealth and reduce the ACD, because the weak shareholder discipline discourages managers to take risk. Exactly opposite to the predictions of the antitakeover hypothesis, the risk-taking hypothesis would predict that classified boards benefit bondholders more if the leverage of a firm is higher, or the credit rating (a proxy for credit condition) is lower, since the conflict between the interests of bondholders and shareholders would be intensified under these scenarios (Bodie and Taggart (1978); John 
and John (1993)). Therefore, a test of these predictions provides a test for the antitakeover hypothesis against the risk-taking hypothesis. The results are presented in Table 5, which I discuss in the next subsection. Overall, the results do not support the antitakeover hypothesis: classified boards have a statistically indistinguishable impact on bond spreads for firms with different leverage ratios; and the beneficial effect of classified boards on bondholders is concentrated in firms with low credit ratings, which supports the risk-taking hypothesis but contradicts the antitakeover hypothesis.

Chava, Livdan and Purnanandam (2009) argue and present evidence that longer maturity loans benefit more from antitakeover provisions because these loans face a higher risk of encountering a takeover. If this argument also extends to publicly traded bonds, I should expect longer maturity bonds to benefit more from classified boards than bonds with shorter maturity. In Model 4 of Table 3, I create a long maturity dummy variable that equals one if the weighted average maturity of all the bonds of a firm in a given year is longer than its sample median, and interact this dummy variable with classified board dummy. The antitakeover hypothesis would predict a negative and significant effect of this interaction term on the cost of debt. However, the results show that Cboard * Long maturity is positive and insignificant, which is inconsistent with the results in Chava, Livdan and Purnanandam (2009) based on loan spreads and the G-index. The coefficient on Cboard becomes even larger with the inclusion of this interaction term.

Francis, Hasan, John and Waisman (2010) show that state antitakeover laws decrease the cost of debt. Therefore, if the antitakeover effect of classified boards drives their negative impact on the cost of debt, it is expected that firms that both have single-class boards and are incorporated in states with few antitakeover laws should incur the highest cost of debt. In other words, a firm with both weak firm-level and state-level takeover defenses should be most vulnerable to hostitle 
takeovers, and therefore bondholders of such a firm should be most concerned. To examine this prediction, I create a variable indicating takeover vulnerability at the state level. I then interact this variable with a dummy variable which indicates the absence of board classification, No_cboard (=1-Cboard). The antitakeover hypothesis would predict this interaction term to be positive and significant. I consider two measures of the state-level takeover vulnerability. In Model 5, I define a variable (State_vul) based on the five state antitakeover statutes in Francis, Hasan, John and Waisman (2010). ${ }^{22}$ Contrary to the prediction of the antitakeover hypothesis, however, the interaction term No_cboard * State_vul is negative and insignificant. State_vul is positive and weakly significant at close to $10 \%$ level, consistent with the results in Francis, Hasan, John and Waisman (2010).

In Model 6, I use another measure of the state-level takeover vulnerability to further examine the antitakeover hypothesis. I define State_G similar to State_vul but based on the 6 antitakeover statutes in the components of the G-index. ${ }^{23}$ Similar to Model 5, the interaction term No_cboard * State_G is negative and insignificant, which is inconsistent with the antitakeover hypothesis.

Overall, the evidence in Table 3 as well as Table 5 does not support the hypothesis that classified boards' reduction in the cost of debt is due to the concern of bondholders for hostile takeovers. These results suggest that the large effect of classified boards on the cost of debt may not come through the takeover channel. I examine the other two channels as discussed in Section 2 in the following two subsections.

\subsection{Risk-taking Hypothesis}

\footnotetext{
${ }^{22}$ Specifically, State_vul is five minus the state antitakeover index, which is the sum of the indicators for the availability of the five state antitakeover statutes: business combination, control share acquisition, fair price, constituencies, and poison pill endorsement.

${ }^{23}$ These are business combination, control share acquisition, fair price, constituencies, antigreenmail, and controlshare cash-out. Specifically, I subtract a state-level antitakeover index from 6 to arrive at State_G, where the index is the sum of the indicators for the availability of the 6 antitakeover statutes.
} 
Absence of the discipline by shareholders, management may opt for a low-risk corporate policy, in an attempt to protect their private benefits from control and the non-diversified human capital investment. Therefore, the beneficial effect of classified boards on bondholders may be explained by the low-risk preference of managers, since bondholders are concerned about the risk-shifting incentive of shareholders to expropriate their wealth. I conduct two types of tests to examine this "risk-taking hypothesis". I first test whether classified boards are indeed associated negatively with the risk-taking of a firm. Since the reduction in the ACD through low-risk taking is expected to be more pronounced when the conflict of interests between shareholders and bondholders is intensified, I also examine a potentially differential impact of classified boards on the cost of debt conditional on scenarios characterized by different degrees of such conflict.

I use Glejser (1969)'s heteroskedasticity test to examine how classified boards affect the variability of a firm's performance. It is expected that low-risk corporate policies are associated with less variable firm performance. I follow Adams, Almeida and Ferreira (2005) and Cheng (2008) and consider three performance measures: monthly stock return, Tobin's Q, and ROA. The Glejser test is conducted in two steps. In the first step regressions are run on performance levels. For monthly stock return I estimate the Fama-French three-factor model. For Tobin's Q and ROA I estimate OLS models with control variables as described in Section 3.2.2, except that I do not control for ROA in the ROA regression. In the second step of the Glejser test, the absolute values of the residuals from the first step regressions are regressed on the variables that may explain the variability of firm performance. I control for the same set of variables as in the Tobin's Q level regression model.

Insert Table 4 about here 
Table 4 reports the results of the second step regressions. Classified boards are associated with a lower variability in firm performance for all three performance measures, and the coefficients are significant at the $5 \%$ and $1 \%$ levels in the stock return and Tobin's Q regressions, respectively. These results are consistent with the risk-taking hypothesis. ${ }^{24}$ The lowrisk taking associated with board classification should inure to the benefit of bondholders.

This benefit should be more pronounced when the divergence of interests between shareholders and bondholders is intensified, since the incentive of shareholders for risk-shifting is stronger and hence the expected ACD are higher under these scenarios. Therefore, the risktaking hypothesis would predict a more significant impact of classified boards on the cost of debt under the scenarios characterized by higher expected ACD. I examine two such scenarios: if a firm is highly levered or if the firm is closer to financial default (Bodie and Taggart (1978); John and John (1993)). I also consider the combination of these two scenarios, under which the ACD are expected to be the greatest. I use the S\&P credit rating (SP_rate) as a proxy for a firm's default likelihood. ${ }^{25}$ Since Bradley and Chen (2010) show that corporate governance matters differentially for bondholders conditional on a firm's creditworthiness, I run regressions separately on the two sub-samples characterized by different levels of the expected ACD. ${ }^{26}$ For leverage I separate the sample based on the median value of leverage in the sample (High leverage $=1$ or 0 ). For credit rating the two sub-samples are stratified on whether the rating is speculative-grade or investment-grade $(\mathrm{SPC}=1$ or 0$)$, following the convention in the literature (e.g., Bhojraj and Sengupta (2003); Klock, Mansi, and Maxwell (2005)). I then multiply High

\footnotetext{
${ }^{24}$ I also examine the relation between within-firm over-time variation of firm performance and classified boards as in Adams, Almeida and Ferreira (2005) and Cheng (2008), and obtain similar results.

${ }^{25}$ I also use Altman's Z-score (Altman (1968)) as a proxy for a firm's default risk. But using this variable reduces the sample size dramatically, and may account for the insignificant results.

${ }^{26}$ Since running regressions by interacting Cboard with dummy variables indicating the different expected ACD would essentially force the coefficients on other variables, including the governance variables to be the same across the sub-samples, which is restrictive given the evidence in Bradley and Chen (2010).
} 
leverage with SPC to consider the combination of these two conditions (High leverage * SPC $=1$ or 0 ). Table 5 reports the regression results on the three types of sub-samples, respectively. I also conduct Chow tests for the statistical differences between the coefficients on classified boards across the sub-samples, and report the p-values.

\section{Insert Table 5 about here}

The results in Table 5 suggest that the significant effect of board classification on the cost of debt is concentrated in highly levered firms, speculative-grade firms, and firms that are both highly levered and speculative-grade. The Chow tests suggest that the coefficients on classified boards across the sub-samples with different leverages are not statistically different, however. But the differences between the coefficients are statistically significant across the other two groups of sub-samples. Overall, the results in Table 5 support the risk-taking hypothesis.

As discussed in Section 4.2, the results in Table 5 also provide further evidence against the antitakeover hypothesis. This hypothesis would predict a more beneficial impact of classified boards on bondholders of firms with low leverages and investment-grade ratings, since these firms are more likely to suffer from an increased leverage and a reduced credit rating due to takeovers. Yet the results in Table 5 are not consistent with these predictions.

\subsection{Disclosure Hypothesis}

Section 2 also discusses a third channel through which board classification may benefit bondholders and reduce the cost of debt. The lessened pressure from takeovers may decrease the incentive of management to obfuscate information disclosure and improve the financial transparency of a firm. To examine this "disclosure hypothesis", I conduct two sets of tests similar to the test of the risk-taking hypothesis in Section 4.3. I first examine whether classified boards are associated with better financial transparency of a firm. Then I test a differential 
impact of classified boards on the cost of debt conditional on the degree of market uncertainty, since financial disclosure should be more valuable to investors when they are more uncertain about the financial condition and performance of the firm (Sengupta (1998)).

I consider three measures of financial transparency: earnings quality, the dispersion of analysts' earnings forecasts, and the incidence of securities class-action lawsuits. As the sample period in this paper saw an increased incidence of declassification as evidenced in the summary statistics of Section 3.3, it is possible that firms whose investors are concerned about financial transparency may also be subject to shareholder activists' proposals to declassify their boards, and be pressured to act upon such proposals. Therefore, a negative relation between transparency and the incidence of single-class board, or equivalently, a positive relation between transparency and classified boards may reflect such self-selection. To reduce this concern, I delete the firmyears which experienced a change in their classification status during the sample period. ${ }^{27}$

Dechow, Ge and Schrand (2010) state that "higher quality earnings provide more information about the features of a firm's financial performance that are relevant to a specific decision made by a specific decision-maker". Therefore, higher earnings quality may signal better financial disclosure. Dechow and Dichev (2002) propose the accrual quality (AQ) as an earnings quality measure, based on the standard deviation of the residuals from the regression of working capital accruals on past, current, and subsequent cash flows. They argue that a higher AQ suggests larger estimation errors and lower earnings quality. McNichols (2002) arguments the AQ model with two additional variables that may also influence current accruals, the change in revenue and gross PPE. Based on the McNichols model, Ecker, Francis, Kim, Olsson, and $\underline{\text { Schipper (2006) }}$

\footnotetext{
${ }^{27}$ Results using the sample with all the firm-years including those with a change in classification status are similar, except that the classified board dummy in the regression of the incidence of class action litigation is only weakly significant at the $10 \%$ level. I also consider an alternative strategy to reduce the concern of reverse causality: I only include firms which did not change their classification status since 1998 in the sample. The results are also similar.
} 
augment the Fama-French three-factor model with the modified "AQ" factor, and propose that the loading on this factor, which they call the e-loading, reflects market participants' perception of the quality of a firm's earnings. Compared with other proxies of earnings quality based on accounting data, e-loading has the advantage of potentially increasing the sample size since the construction of this variable relies on stock returns. Ecker, Francis, Kim, Olsson, and Schipper (2006) run a horse race between e-loadings constructed from different proxies of earnings quality, and conclude that none of the other measures systematically dominates e-loadings based on AQ. I use the e-loading based on the AQ factor as a proxy for earnings quality in this paper. ${ }^{28}$ To be consistent with the idea that higher value of the proxy indicates better earnings quality, I define the earnings quality as the negative of the e-loading. As noted by Dechow and Dichev (2002) and Ecker, Francis, Kim, Olsson, and Schipper (2006), AQ and e-loadings measure total abnormal accruals, which include the "innate" part determined by firm-specific characteristics, and the "discretionary" part determined by management. Since I am testing the potential effect of board classification on managerial incentive for information disclosure, the discretionary part is my primary concern. It is therefore important to net out the innate determinants of the earnings quality in the regression model. Dechow and Dichev (2002) identify several firm characteristics that are significantly associated with their AQ: firm size, the length of operating cycle, the standard deviation of sales and cash flows, and the incidence of negative earnings. I control for these variables in the regression model. I also control for ROA, equity volatility, and several governance variables that may influence the financial disclosure of management, which include the three CEO power variables as discussed in Section 3.2.2, CEO shareholdings and tenure, board size and independence, and institutional and block holdings. Model 1 in Table 6 presents the regression results.

\footnotetext{
${ }^{28}$ I thank Frank Ecker for providing the e-loadings data.
} 


\section{Insert Table 6 about here}

Model 1 suggests that classified boards are associated positively with earnings quality, and the coefficient on Cboard is significant at the $1 \%$ level. This result complements the evidence in Zhao and Chen (2009), who document that the passage of the state antitakeover laws in the 1980s is associated with an increased earnings quality, as proxied by abnormal accruals based on Gaver, Gaver and Austin (1995) and the informativeness of earnings. The evidence in Model 1 supports the disclosure hypothesis. ${ }^{29}$

Inadequate or low-quality financial disclosure may also increase the dispersion of analysts' earnings forecasts, which may signal high risk of financial fraud (Chava, Kumar and Warga (2010)). In Model 2 of Table 6, I examine the relation between board classification and the dispersion of analysts' earnings forecasts. The control variables are similar to Model 1, except that I do not control for the innate determinants of earnings quality (except for firm size). Consistent with the disclosure hypothesis, the coefficient on the classified board dummy is negative and significant at the $5 \%$ level, which suggests that classified boards are associated with a lower dispersion of earnings forecasts and hence a lower risk of financial fraud.

Higher fraud risk may not necessarily lead to financial fraud. Therefore, in Model 3, I examine the effect of classified boards on the incidence of class action litigation, which is often brought about by shareholders in response to corporate fraud. Following many others (e.g., Gande and Lewis (2009)), I obtain the data on the filings of federal class action lawsuits from the Securities Class Action Clearinghouse database at Stanford University. I code the incidence of class action litigation as a dummy variable that equals one if shareholders filed any class action

\footnotetext{
${ }^{29}$ Model 1 also suggests that operating cycle and the incidence of negative earnings are negatively associated with earnings quality, which is consistent with the results in Dechow and Dichev (2002). The insignifiant effects of the standard deviations of cash flows and sales are not consistent with Dechow and Dichev (2002), but the signifiance of these two variables may be subsumed by equity volality. Indeed, in unreported analysis, I find that without including equity volatility, both standard deviations are negative and significantly associated with earnings quality.
} 
lawsuit against the firm in a given year, regardless of how many times they did so. ${ }^{30} \mathrm{I}$ employ a probit model to run the regression on the class action dummy. In addition to the control variables in Model 2, I also follow Gande and Lewis (2009) and control for annual stock return in the past year, share turnover and earnings surprise. Both stock returns and earnings surprise are expected to be negatively associated with the propensity of shareholders to sue. The turnover of shares reflects the probability that a share was traded in the past year, which may increase the likelihood of the firm to be sued, since a typical class action lawsuit covers shareholders who buy shares over the previous year. ${ }^{31}$ Consistent with the disclosure hypothesis, the coefficient on classified boards in Model 3 is negative and significant at the 5\% level. This result suggests that classified boards are associated with a lower incidence of financial fraud.

Overall, the results in Table 6 provide direct evidence that board classification is associated with better information disclosure of the firm, which is reflected in a higher earnings quality, a lower dispersion of analysts' earnings forecasts, and a lower incidence of class action lawsuits.

To further test the disclosure hypothesis, I examine the potential differential impact of classified boards on the cost of debt conditional on the degree of market uncertainty. Financial disclosure should be valued more by investors when they are more uncertain about the financial condition and performance of a firm (Sengupta (1998)). If board classification promotes the incentive of management to disclose more and truthful information to the market, it may also benefit creditors and reduce the cost of debt more under higher degree of market uncertainty. I

\footnotetext{
${ }^{30}$ Results using the number of class action lawsuits in a given year for a firm are similar.

${ }^{31}$ Gande and Lewis (2009) also identify several other variables that are significantly associated with shareholders' propensity to file class action lawsuits, including industry litigation intensity, a dummy variable indicating whether the firm was sued before, and industry dummies representing industries that may be more or less likely to be sued. They also document that the CEO bonus compensation and its interaction with a negative ROA dummy are significantly associated with the litigation likelihood. The industry controls in this paper should alleviate the concerns of the industry effects driving the incidence of class action litigation. In unreported analysis, I control for a variable indicating past class action defendents, CEO bonus and its interaction with a dummy variable for negative ROA. The results are similar. These additional control variables are not significant.
} 
employ three proxies of market uncertainty. Following Sengupta (1998), my first proxy uses the volatility of stock returns. Higher level of uncertainty regarding the financial performance of a firm should be reflected in more volatile stock returns. Diamond and Verrecchia (1991) argue that smaller firms face more severe problem of information asymmetry. In an attempt to mitigate this problem, Vermaelen (1981) document that smaller firms engage in more share repurchases to signal positive information. Therefore, my second proxy for market uncertainty is firm size as proxied by the $\log$ of market capitalization. It is expected that smaller firms face higher uncertainty regarding their financial performance, ceteris paribus. My third market uncertainty proxy is the dispersion of analysts' earnings forecasts. A higher dispersion of analysts' opinions represents more uncertainty over a firm's financial performance (Krishnaswami and Subramanian (1999); Duchin, Matsusaka and Ozbas (2010)). ${ }^{32}$ Since the three proxies of market uncertainty may be correlated with the credit condition of a firm, ${ }^{33}$ similar to Table 5 , I run separate regressions on sub-samples stratified by the median values of the respective proxies of market uncertainty. This considers the fact that other control variables such as governance variables may also have a differential effect on the cost of debt conditional on market uncertainty (Bradley and Chen (2010)). Table 7 presents the results. Similar to Table 5, p-values for the Chow tests for the statistical differences between the coefficients on classified boards across the sub-samples are also reported.

The results in Table 7 accord with the prediction of the disclosure hypothesis. The beneficial effect of classified boards on the cost of debt is concentrated in smaller firms and firms with

\footnotetext{
${ }^{32}$ I also entertain the number of analysts following a firm and the analysts forecast error as two other proxies for market uncertainty. Though the significant results of classified boards on the cost of debt are concentrated in subsamples of firms with few analysts following and higher analysts forecast error, which is consistent with the prediction of the disclosure hypothesis, the Chow tests do not detect statistical differences between the coefficients on classified boards across the sub-samples.

${ }^{33}$ For example, Campbell and Taksler (2003) show that equity volatility is positively associated with bond yields.
} 
more volatile stock returns and higher dispersion of analysts' earnings forecasts. The Chow tests also suggest statistical significance across the sub-samples. Therefore, Table 7 shows that classified boards benefit bondholders more when there is a higher degree of market uncertainty.

Collectively, the results in Tables 3-7 are not consistent with the antitakeover hypothesis. Instead, the evidence supports both the risk-taking and disclosure hypotheses. These results suggest that the strong beneficial effect of classified boards on bondholders and the reduction in the cost of debt may not come through the takeover channel, but from the low-risk preference of undisciplined managers, as well as the improved managerial incentive for financial disclosure due to their lessened concern for takeovers.

\section{The Differential Impact of Classified Boards on Firm Performance}

Since a lower cost of debt reduces the interest expenses incurred by a firm, it may also matter for shareholders and firm performance. In this section I examine the effect of classified boards on firm performance in light of their significant savings of interest costs.

Prior literature generally documents a negative effect of classified boards on firm performance, presumably in reflection of their antitakeover effect (Bebchuk and Cohen (2005); Faleye (2007); Masulis, Wang and Xie (2007); Zhao and Chen (2008); Bebchuk, Cohen and Wang (2011)). The evidence in this paper also suggests another channel through which classified boards may hurt shareholders - the low-risk taking by undisciplined managers. In Model 1 of Table 8 , I attempt to replicate the results obtained in the literature by testing the average effect of classified boards on firm performance as proxied by Tobin's Q. The control variables are as described in Section 3.2.2. Indeed, the coefficient on classified boards is negative and significant at the $5 \%$ level. Therefore, the results confirm the evidence documented in the literature. 
However, better financial transparency associated with classified boards should benefit bondholders as well as shareholders. Theory and empirical evidence also suggest that shareholders benefit from the saving of interest costs associated with a lower cost of debt (see, e.g., Bradley and Chen (2011) for the empirical evidence). Therefore, given the significant impact of classified boards on the cost of debt especially under the scenarios characterized by strong agency conflict between shareholders and bondholders and high market uncertainty, it is an open question as to whether firm performance may be less negatively impacted by or even improved with classified boards under these scenarios. I examine this possibility in the rest of the models in Table 8. Admittedly, firm performance is also determined by factors beyond the cost of debt, such as cash flows and the cost of equity. Therefore, the results are only meant to be suggestive. To be consistent with prior specifications it is best to run regressions on firm performance and classified boards conditional on sub-samples similar to Tables $5 \& 7$. But this would suggest that 12 columns of results be reported. For the sake of space, I interact dummy variables proxying for high levels of expected ACD and market uncertainty as defined in Tables $5 \& 7$ with the classified board dummy respectively. In unreported robustness checks, I run regressions conditional on sub-samples and obtain qualitatively similar results. ${ }^{34}$

Insert Table 8 about here

The interaction terms, High leverage * Cboard, SPC * Cboard, High leverage * SPC * Cboard in Models 2-4 are all positive and significant at the 5\% level or above while classified boards are negative and significant. The F-tests suggest that the net impact of classified boards on Tobin's Q is statistically insignificant when a firm is highly-levered, and positive and significant when a

\footnotetext{
${ }^{34}$ The only difference is that there is no statistical difference between the coefficients on classified boards for small firms relative to large firms, based on a Chow test. Therefore, the results suggest that despite the significantly differential impact of classified boards on the cost of debt conditional on market uncertainty, the impact of classified boards on firm performance is independent of the level of market uncertainty.
} 
firm is lowly-rated or both highly-levered and lowly-rated. ${ }^{35}$ Therefore, these results suggest that classified boards are benign to firm performance when the agency conflict between shareholders and bondholders is severe, which is consistent with the idea that board classification's dramatic reduction in the cost of debt under these scenarios may be sufficient to balance the net costs of classified boards on shareholders.

The differential effect of classified boards on firm performance conditional on the degree of market uncertainty is less pronounced, however. Among the three interaction terms built on the three proxies of market uncertainty, only Small size * Cboard is positive and weakly significant at the $10 \%$ level. But as footnote 34 suggests, in more unrestrictive regressions conditional on sub-samples with different firm sizes, the coefficients on the classified board dummy across the sub-samples are not statistically different at the conventional levels based on a Chow test. Therefore, despite the more significant effect of classified boards on the cost of debt under higher degree of market uncertainty as shown in Table 7, classified boards have a similar impact on firm performance regardless of the level of market uncertainty. This result might reflect a

\footnotetext{
${ }^{35}$ Though the differential effect of classified boards on the cost of debt conditional on leverage as shown in Model 2 is consistent with my argument that classified boards benefit bondholders as well as shareholders more when the expected ACD are high, an alternative hypothesis may also explain this result. If debt reduces the agency costs of free cash flows (Jensen (1986)), then highly-levered firms may not be so concerned about weak shareholder discipline induced by board classification. This may also explain the insignificant effect of classified boards on Tobin's Q when leverage is high. This argument rests on the substitubility between leverage and a single-class board in reducing the agency costs. Rigorously ruling out this hypothesis is beyond the scope of this paper. However, I present three pieces of evidence which suggests that the "substitubility hypothesis" may not explain the results in Model 2. First, this hypothesis may not easily explain the results in Models $3 \& 4$, where I show that classified boards improve the performance of firms characterized by both high leverage and speculative-grade ratings. Second, the empirical evidence is not consistent with the substitubility between debt and single-class boards. Jiraporn and Liu (2008) find that classified boards are associated with a lower, rather than a higher level of leverage, which is contrary to the prediction of the "substitability hypothesis". Finally, in unreported analysis, I examine one implication of this hypothesis that leverage should benefit a firm more if the free cash flow of the firm is high. Following the definition of free cash flow in Lehn and Poulsen (1989), I find that the interaction term between the high free cash flow dummy and leverage is negatively associated with Tobin's Q, which is exactly opposite to the prediction of the "substitubility hypothesis". Also, the "substitubility hypothesis" would predict that the reduction in the agency costs of free cash flows due to leverage should be more pronounced for a firm with both a high level of free cash flow and a classfied board structure. But my results are also not consistent with this prediction.
} 
differential effect of classified boards on other factors that may determine firm performance. But sorting out these issues is beyond the scope of this paper and is left for future research.

Overall, the results in Table 8 provide some interesting addition to the consensual adverse effect of classified boards on firm performance as documented in the literature. The evidence suggests that despite the average negative effect of classified boards on firm performance, board classification seems benign to performance when the expected ACD are high, perhaps in reflection of its more significant reduction in the cost of debt under these scenarios.

\section{Robustness Checks}

\subsection{Endogeneity}

As noted previously, most classified boards were established in the 1980s and changed little afterwards. This stability of the incidence of classified boards may alleviate the concerns for endogeneity, in particular reverse causality. Most board classifications after 1990 have occurred at the time of IPOs (Bebchuk and Cohen (2005); Masulis, Wang and Xie (2007); Bates, Becher and Lemmon (2008)). In unreported analysis I exclude all firms that went public after 1990. The results are similar. Besides the "pre-determined" nature of most classified boards, reverse causality may not explain the negative association between classified boards and bond spreads. If management responds to deteriorating firm performance by classifying its board in an attempt to fend off potential takeovers, a positive relation between classified boards and bond spreads is expected. Nevertheless, endogeneity issue is always present and notoriously hard to tackle. ${ }^{36} \mathrm{I}$ conduct two additional tests in this subsection to further address this issue. I focus on the cost of debt results for two reasons. First, the literature has addressed the endogeneity issue for the

\footnotetext{
${ }^{36}$ In the context of classified boards, researchers have used instrumental-variable (IV) approach to solve this issue. Faleye (2007) and Ahn, Goyal and Shrestha (2010) use the incorporation in Massachusetts as an IV for the exogenous variation of classified boards, since Massachusetts passed a state law in 1990 which requires all public firms incorporated in this state to have classified boards by default. Unfortunatey, this IV does not work in the context of this paper, since out of the 389 firms in my sample, only 4 are incorporated in Massachusetts.
} 
performance effect of classified boards extensively (e.g., Bebchuk and Cohen (2005); Faleye (2007); Bebchuk, Cohen and Wang (2011)). Second, I focus on the differential impact of classified boards on firm performance, which may also alleviate the endogeneity concerns.

Insert Table 9 about here

I first follow Bebchuk and Cohen (2005) and restrict the sample to those firms that were covered by the RiskMetrics Governance Database but did not change their board classification status since 1990. Reverse causality may not be a serious concern for these firms. This way of constructing the sample reduces the sample size to 1,009 firm-years. I rerun the regressions in Models $1 \& 3$ of Table 2 . In light of the smaller sample size, I also add rating dummies to Model 3 of Table 2, instead of following the specification as in Model 5. The results for these three model specifications are reported in Models 1-3 of Table 9. Classified boards continue to be negatively associated with bond spreads, albeit the significance becomes weaker (at the $10 \%$ level), presumably reflecting the reduced sample size. But the magnitudes of the coefficients on classified boards are even larger than those reported in Table 2 .

Even if reverse causality may not be a serious concern, the study may still suffer from an omitted variable bias. However, my extensive control of financial, rating, and governance variables may mitigate this bias significantly. But as noted earlier, the lack of data on some issue characteristics (such as callability, convertibility, etc.) may still be a source of bias. To consider this issue, I run change regression on bond spreads. This specification is immune to the bias induced by omitted but time-invariant variables, as would be the case with the issue characteristics. Since very few boards changed their classification status during the sample period, running change regressions on the whole bond sample would dilute the power of the tests dramatically, as most changes of classified board dummy are zero. Therefore, I only include 
firms who classified or declassified their boards within the sample period. As a result, the sample only has 35 observations. Consequently, in Model 4 of Table 9, I include the changes of the control variables as in Model 3 of Table 2 (except for the change of bond age), and Fama-French 12-industry dummies. Since I include the change in the Net G-index, this considers the possibility that firms may be more willing to declassify their boards if they have installed other takeover defenses, which introduces a correlation between the change in classified boards and the change in the Net G-index. The results in Model 4 show that $\Delta$ Cboard is negative and significant at the $5 \%$ level, consistent with the results in Table 2 . Therefore, the results from the change regression suggest that the effect of classified boards on the cost of debt as documented earlier is immune to the consideration of omitted but time-invariant variables.

Based on the above analysis, even though I can not conclude definitively that endogeneity, including omitted variable bias, is not driving the results in the paper, it appears unlikely that endogeneity is a serious concern.

\subsection{Sample Selection Bias}

There is an additional concern for the cost of debt results since the sample only includes firms with publicly traded bonds. I use Heckman's two-step selection model to address this potential sample selection bias. In the first step, I use three instruments for access to the public bond market: firm age, inclusion in the S\&P 500 index, and listing on NYSE. Other control variables include firm size, market-to-book ratio, ROA, equity volatility, leverage, and year and industry dummies. From the first step I calculate the inverse Mills ratio. In the second step, I include this ratio as an additional variable in the spread regression. The results from this second step are shown in Model 1 of Table 10. Classified boards continue to be negative and significant for bond spreads, which implies that sample selection bias is not a serious concern in this study. 
Insert Table 10 about here

\subsection{Bond Covenants}

Bradley and Roberts (2004) show that the inclusion of bond covenants can reduce bond spreads. Since I do not have the covenant controls in my spread regressions, this may add to the omitted variable bias. To examine this possibility, I follow Smith and Warner (1979) and Chava, Kumar and Warga (2010), and group the covenants of each bond into four categories: investment restrictions, subsequent financing restrictions, dividend restrictions, and event-related restrictions. The issue-level dummy variables on the incidence of each of these four categories of covenants are then aggregated into four firm-level variables, similar to the construction of firmlevel bond spreads. I control for these four covenant variables in the spread regression. Model 2 of Table 10 reports the results. Compared with Table 2, sample size drops significantly to 1,091 observations. Classified boards continue to be negative, but only significant at the $10 \%$ level. The results also indicate that covenants on investment restrictions are associated with a lower cost of debt. Model 2 suggests that the effect of classified boards on the cost of debt is robust to the inclusion of covenant controls.

\subsection{Charter versus Bylaw Based Classified Boards}

Board classification can be established either in corporate charters or bylaws. Bebchuk and Cohen (2005) argue that bylaw-based classified boards are not as effective an antitakeover device as charter-based ones since, compared with charters, shareholders have greater power to amend bylaws without boards' consent. ${ }^{37}$ In unreported analysis, I repeat the analysis using charter-based classified boards. Data for these boards is obtained from Lucian Bebchuk's website. Unfortunately, the data only covers years between 1990 and 2002. So there is only two

\footnotetext{
${ }^{37}$ However, as Bates, Becher and Lemmon (2008) point out, many firms also restrict the ability of shareholders to change board characteristics established in the bylaws without the consent of the board itself.
} 
years' intersection with my sample period. ${ }^{38}$ As a result, sample size drops to only 511 observations for the cost of debt regressions. Nevertheless, the results still hold qualitatively. ${ }^{39}$

\section{Conclusion}

This paper conducts an analysis of the effects of classified boards on the cost of debt as well as the implications on firm performance. The empirical results suggest that classified boards are strongly associated with a lower cost of debt, and the effect is robust to the inclusion of an extensive control of financial and governance variables the literature has shown to be relevant to the cost of debt.

I then examine three hypotheses which are built on three channels through which board classification may benefit bondholders. I find that the antitakeover effect of classified boards may not explain their reduction in the cost of debt. Instead, the results in this paper are consistent with the notion that undisciplined managers and directors as afforded by board classification conduct low-risk corporate policies, which coincidently redounds to bondholders' benefit and reduces the agency costs of debt. Under the scenarios that the agency conflict between shareholders and bondholders is pronounced and hence the expected ACD are high, I show that classified boards also have a more significant effect on the cost of debt. The results also suggest that classified boards are associated with better financial transparency, which also benefits bondholders. This is consistent with the idea that the lessened pressure from takeovers reduces

\footnotetext{
${ }^{38}$ The intersection is two years since I assume that the incidence of board classification is the same as in the previous year, if that year's data is not available. This follows the convention in the literature.

${ }^{39}$ Specifically, charter-based classified boards are negatively associated with bond spreads. The evidence suggests that charter-based board classification reduces managerial risk-taking, although there is no statistical difference between the coefficients on classified boards across the sub-samples characterized by different agency conflict between shareholders and bondholders. The results show that charter-based classified boards are associated with higher earnings quality and a lower dispersion of analysts' earnings forecasts, and the differential impact of classified boards conditional on market uncertainty still holds. The differential impact of charter-based classified boards on Tobin's Q also holds conditional on agency conflict between shareholders and bondholders. Interestingly, the results also show that charter-based classified boards have a less adverse impact on firm performance for smaller firms.
} 
managerial incentive to obfuscate financial report and improves information disclosure. Since financial transparency is more valuable for investors when they are more uncertain about the financial condition and performance of a firm, I find that classified boards also reduce the cost of debt more under higher level of market uncertainty.

Finally, I connect the cost of debt results to a potentially differential impact of classified boards on firm performance, in consideration of the fact that the savings from interest costs also benefit shareholders. Confirming the evidence in the literature, I find an average negative effect of classified boards on firm performance. However, consistent with a more significant effect of board classification on the cost of debt when the expected ACD are higher, I document a benign impact of classified boards on firm performance under these scenarios. 


\section{Appendix \\ Table A1. Variable Definitions}

\begin{tabular}{|c|c|}
\hline Variable & Definitions \\
\hline Cboard & Dummy variable that equals one if the board election is classified (staggered), and zero otherwise \\
\hline Spread & $\begin{array}{l}\text { Weighted average spread of all the senior unsecured bonds of a firm, with the weight being the issue size of a bond as a percentage } \\
\text { of the aggregate issue sizes of all the bonds of the issuing firm in the sample in a given year. The spread for an individual bond is } \\
\text { defined as the difference between the yield-to-maturity (YTM) of the bond and the YTM of the Treasury bond matched by the } \\
\text { closest maturity. }\end{array}$ \\
\hline SP_rate & $\begin{array}{l}\text { Numerical S\&P credit ratings (data280), ranges from 1(default) to } 22 \text { (AAA). If SP_rate equals } 12 \text {, it stands for "BB+" rating, at or } \\
\text { below which the firm is regarded as speculative grade. }\end{array}$ \\
\hline Rate & $\begin{array}{l}\text { Grouped seven categories out of the } \mathrm{S} \& \mathrm{P} \text { credit ratings (data } 280 \text { ). Specifically, rate }=1 \text { if } \mathrm{Rating}<=\mathrm{CCC}+\text {; rate }=2 \text { if } \\
\mathrm{CCC}+<\text { Rating }<=\mathrm{B}+\text {; rate }=3 \text { if } \mathrm{B}+<\mathrm{Rating}<=\mathrm{BB}+\text {; rate }=4 \text { if } \mathrm{BB}+<\text { Rating }<=\mathrm{BBB}+\text {; rate }=5 \text { if } \mathrm{BBB}+<\mathrm{Rating}<=\mathrm{A}+\text {; rate }=6 \text { if } \\
\mathrm{A}+<\text { Rating }<=\mathrm{AA}+\text {; rate }=7 \text { if Rating }>\mathrm{AA}+\text {. Rating dummies are based on this variable. }\end{array}$ \\
\hline Q & Tobin’s Q ((data6-data60-data74+data199*data25)/data6) \\
\hline Duration & $\begin{array}{l}\text { Weighted average duration of all the senior unsecured bonds of the firm, with the weight being the issue size of a bond as a } \\
\text { percentage of the total aggregate issue sizes of all the bonds of the issuing firm in the sample in a given year }\end{array}$ \\
\hline Convexity & $\begin{array}{l}\text { Weighted average convexity of all the senior unsecured bonds of the firm, with the weight being the issue size of a bond as a } \\
\text { percentage of the total aggregate issue sizes of all the bonds of the issuing firm in the sample in a given year }\end{array}$ \\
\hline Bond age & $\begin{array}{l}\text { Weighted average age of all the senior unsecured bonds of the firm, with the weight being the issue size of a bond as a percentage of } \\
\text { the total aggregate issue sizes of all the bonds of the issuing firm in the sample in a given year }\end{array}$ \\
\hline ROA & Return on asset (data18/data6) \\
\hline Book size & Natural logarithm of total asse $s(\log ($ data6 $))$ \\
\hline Mkt size & Natural logarithm of market capitalization $(\log ($ data $199 *$ data25)) \\
\hline Leverage & Long term debt plus debt in current liabilities over total assets ((data9+data34)/data6) \\
\hline Volatility & Standard deviation of the stock returns over the past 72 months \\
\hline $\mathrm{Mb}$ & Market-to-book ratio ((data6-data60+data199*data25)/data6) \\
\hline Sub debt & Dummy variable that equals one if the firm has subordinated debt (data80), and zero otherwise \\
\hline G-index & $\begin{array}{l}\text { Antitakeover/managerial entre pchment index in Gompers, Ishii, and Metrick (2003), defined as the sum of the } 24 \text { indicators for } \\
\text { antitakeover/managerial entrer chment mechanisms }\end{array}$ \\
\hline
\end{tabular}


Net G-index

L-index

Poison pill

CEO options

CEO shares

Indep director

Board size

Inst shares

Block shares

Earnings quality

Analyst forecast dispersion

Security class action

CEO tenure

CEO senior

CEO sole insider

CEO chair

Operating cycle

Sigma_sales

Sigma_cfo

Negative earning

Stock return

Share turnover

Earnings surprise
G-index - Cboard, where the G-index is the sum of the 24 indicators for antitakeover/managerial entrenchment mechanisms (Gompers, Ishii and Metrick (2003))

The sum of the three indicators for whether the firm has provisions to limit the personal liability of their directors, or indemnify their personal expenses involved in litigation at the charter/bylaw, or contract levels (Bradley and Chen (2011).

Dummy variable that equals one if the firm has a poison pill, and zero otherwise

The Black-Scholes value of CEO option grants as a percentage of CEO total compensation

CEO shares as a percentage of total shares outstanding

Percentage of independent directors to total board size

The number of board members

Percentage of institutional shareholdings

Percentage of block institutional shareholdings with at least $5 \%$ shares

The negative of the loadings on the accrual quality (AQ) factor in a four factor model which also includes the Fama-French three factors, where $\mathrm{AQ}$ is defined as the standard deviation of the residuals from the regressions of the change in working capital on past, current, and subsequent cash flow from operations (Ecker, Francis, Kim, Olsson, and Schipper (2006)).

The standard deviation of the analyst EPS forecasts for the next fiscal year, scaled by the absolute value of the mean forecast

Dummy variable that equals one if the firm is the target of a security class action litigation in a given year, and zero otherwise The tenure for CEO in years

Dummy variable that equals one if the CEO's tenure is greater than or equal to the number of years since the firm went public, and zero otherwise.

Dummy variable that equals one if the CEO is the only insider on the board, and zero otherwise.

Dummy variable that equals one if the CEO is also the chairman of the board, and zero otherwise.

The log of the length of operating cycle $(\log (360 /($ data12/data 2$)+360 /($ data $41 /$ data3 $)))$

Standard deviation of sales (data12) scaled by total assets over the past 10 years (requires at least five non-missing observations over the past 10 years)

Standard deviation of cash flow from operations (data308) scaled by total asset; over the past 10 years (requires at least five nonmissing observations over the past 10 years)

The proportion of the firm-years with negative earnings (data18) to total number of firm-years over the past 10 years (requires at least five non-missing observations over the past 10 years)

Annual cumulative stock return

The average ratio of monthly trading volume to total shares outstanding over the past 12 months.

The standardized unexpected earnings, calculated as the difference between the actual earnings per share (EPS) and the consensus 
forecasted EPS scaled by the standard deviation of the earnings forecasts.

Capexp

Firm age

Segments
Capital expenditure as a percentage of total assets, with missing value coded as zero (data128/data6)

Natural logarithm of the number of years since the firm was listed in CRSP

Natural logarithm of the number of business segments of the firm 


\section{References}

Adams, Renee, Heitor Almeida, and Daniel Ferreira, 2005, Powerful CEOs and their impact on corporate performance, Review of Financial Studies 18, 1403-1432.

Aggarwal, Rajesh K., and Andrew A. Samwick, 1999, The other side of the trade-off: the impact of risk on executive compensation, Journal of Political Economy 107, 65-105.

Ahn, Seoungpil, Vidhan K. Goyal, and Keshab Shrestha, 2010, The differential effects of classified boards on firm value, Working Paper, National University of Singapore.

Altman, Edward I., 1968, Financial ratios, discriminant analysis and the prediction of corporate bankruptcy, Journal of Finance 23, 589-609.

Anderson, Roland C., Sattar A. Mansi, and David M. Reeb, 2004, Board characteristics, accounting report integrity, and the cost of debt, Journal of Accounting \& Economics 37, 315-342.

Ashbaugh-Skaife, Hollis, Daniel W. Collins, and Ryan LaFond, 2006, The effects of corporate governance on firms' credit ratings, Journal of Accounting \& Economics 42, 203-243.

Bates, Thomas W., David A. Becher, and Michael L. Lemmon, 2008, Board classification and managerial entrenchment: evidence from the market for corporate control, Journal of Financial Economics 87, 656677.

Bebchuk, Lucian A., John C. IV Coates, and Guhan Subramanian, 2002, The powerful antitakeover force of staggered boards: theory, evidence, and policy, Stanford Law Review 54, 887-951.

Bebchuk, Lucian A., and Alma Cohen, 2005, The costs of entrenched boards, Journal of Financial Economics 78, 409-433.

Bebchuk, Lucian, Alma Cohen, and Allen Farrell, 2009, What matters in corporate governance? Review of Financial Studies 22, 783-827.

Bebchuk, Lucian, Alma Cohen, and Charles C.Y. Wang, 2011, Staggered boards and the wealth of shareholders: evidence from a natural experiment, Working Paper, Harvard University.

Bertrand, Marianne, and Sendhil Mullainathan, 2003, Enjoying the quiet life? corporate governance and managerial preferences, Journal of Political Economy 111, 1043-1075.

Bhojraj, Sanjeev, and Partha Sengupta, 2003, Effect of corporate governance on bond ratings and yields: The role of institutional investors and outside directors, Journal of Business 76, 455-475.

Billett, Matthew T., Tao-Hsien D. King, and David C. Mauer, 2004, Bondholder wealth effects in mergers and acquisitions: New evidence from the 1980s and 1990s, Journal of Finance 59, 107-135.

Bodie, Zvi, and Robert A. Taggart, 1978, Future investment opportunities and value of call provision on a bond, Journal of Finance 33, 1187-1200.

Bradley, Michael, and Dong Chen, 2010, Corporate governance, credit conditions, and the cost of debt, Working Paper, University of Baltimore.

Bradley, Michael, and Dong Chen, 2011, Corporate governance and the cost of debt: evidence from director limited liability and indemnification provisions, Journal of Corporate Finance 17, 83-107.

Bradley, Michael, and Michael Roberts, 2004, The structure and pricing of corporate debt covenants, Working Paper, Duke University.

Campbell, John Y., and Glen B. Taksler, 2003, Equity volatility and corporate bond yields, Journal of Finance 58, 2321-2349.

Chava, Sudheer, Praveen Kumar, and Arthur Warga, 2010, Managerial agency and bond covenants, Review of Financial Studies 23, 1120-1148.

Chava, Sudheer, Dmitry Livdan, and Amiyatosh Purnanandam, 2009, Do shareholder rights affect the cost of bank loans?, Review of Financial Studies 22, 2973-3004.

Cheng, Shijun, 2008, Board size and the variability of corporate performance, Journal of Financial Economics 87, 157-176.

Core, John E., Wayne R. Guay, and Tjomme O. Rusticus, 2006, Does weak governance cause weak stock returns? An examination of firm operating performance and investors' expectations, Journal of Finance 61, 655687.

Cremers, K. J. Martijn, Vinay B. Nair, and Chenyang Wei, 2007, Governance mechanisms and bond prices, Review of Financial Studies 20, 1359-1388.

Crutchley, Claire E., Jacqueline L. Garner, and Beverly B. Marshall, 2002, An examination of board stability and the long-term performance of initial public offerings, Financial Management 31, 63-90.

Daines, Robert, and Michael Klausner, 2001, Do IPO charters maximize firm value? Antitakeover protection in IPOs, Journal of Law, Economics, and Organization 17, 83-120. 
Dechow, Patricia M., and Ilia D. Dichev, 2002, The quality of accruals and earnings: the role of accrual estimation errors, The Accounting Review 77, 35-59.

Dechow, Patricia M., Weili Ge, and Catherine Schrand, 2010, Understanding earnings quality: A review of the proxies, their determinants and their consequences, Journal of Accounting \& Economics 50, 344-401.

Del Guercio, Diane, Laura Seery, and Tracie Woidtke, 2008, Do boards pay attention when institutional investor activists "just vote no"?, Journal of Financial Economics 90, 84-103.

Diamond, Douglas W., and Robert E. Verrecchia, 1991, Disclosure, liquidity, and the cost of capital, Journal of Finance 46, 1325-1359.

Duchin, Ran, John G. Matsusaka, and Oguzhan Ozbas, 2010, When are outside directors effective?, Journal of Financial Economics 96, 195-214.

Duffie, Darrell, and David Lando, 2001, Term structure of credit spreads with incomplete accounting information, Econometrica 69, 633-664.

Ecker, Frank, Jennifer Francis, Irene Kim, Per M. Olsson, and Katherine Schipper, 2006, A returns-based representation of earnings quality, Accounting Review 81, 749-780.

Ertimur, Yonca, Fabrizio Ferri, and Stephen R. Stubben, 2010, Board of directors' responsiveness to shareholders: evidence from shareholder proposals, Journal of Corporate Finance 16, 53-72.

Fahlenbrach, Rudiger, Angie Low, and Rene M. Stulz, 2010, The dark side of outside directors: do they quit when they are most needed?, Working Paper, Ohio State University.

Faleye, Olubunmi, 2007, Classified boards, firm value, and managerial entrenchment, Journal of Financial Economics 83, 501-529.

Fich, Eliezer M., and Anil Shivdasani, 2007, Financial fraud, director reputation, and shareholder wealth, Journal of Financial Economics 86, 306-336.

Francis, Bill, Iftekhar Hasan, Kose John, and Maya Waisman, 2010, The effect of state antitakeover laws on the firm's bondholders, Journal of Financial Economics 96, 127-154.

Fu, Huijing, and Mark H. Liu, 2008, Anti-takeover provisions and corporate disclosure, Working Paper, University of Kentucky.

Gande, Amar, and Craig M. Lewis, 2009, Shareholder-initiated class action lawsuits: shareholder wealth effects and industry spillovers, Journal of Financial and Quantitative Analysis 44, 823-850.Georgeson, 2006, Annual corporate governance review.

Gaver, Jennifer J., Kenneth M. Gaver, and Jeffrey R. Austin, 1995, Additional evidence on bonus plans and income management, Journal of Accounting \& Economics 19, 3-28.

Ghosh, Aloke, and Prem C. Jain, 2000, Financial leverage changes associated with corporate mergers, Journal of Corporate Finance 6, 377-402.

Glejser, H., 1969, A new test for heteroskedasticity, Journal of the American Statistical Association 64, 316-323.

Gompers, Paul, Joy Ishii, and Andrew Metrick, 2003, Corporate governance and equity prices, Quarterly Journal of Economics 118, 107-155.

Graham, John R., Campbell R. Harvey, and Shiva Rajgopal, 2005, The economic implications of corporate financial reporting, Journal of Accounting \& Economics 40, 3-73.

Guo, Re-Jin, Timothy A. Kruse, and Tom Nohel, 2008, Undoing the powerful anti-takeover force of staggered boards, Journal of Corporate Finance 14, 274-288.

Higgins, Robert C., and Lawrence D. Schall, 1975, Corporate bankruptcy and conglomerate merger, Journal of Finance 30, 93-113.

Jensen, Michael C., 1986, Agency costs of free cash flow, corporate-finance, and takeovers, American Economic Review 76, 323-329.

Jensen, Michael C., and William H. Meckling, 1976, Theory of firm - managerial behavior, agency costs and ownership structure, Journal of Financial Economics 3, 305-360.

Jiraporn, Pornsit, and Yixin Liu, 2008, Capital structure, staggered boards, and firm value, Financial Analysts Journal 64, 49-60.

John, Kose, Lubomir Litov, and Bernard Yeung, 2008, Corporate governance and risk-taking, Journal of Finance 63, 1679-1728.

John, Kose, and Lemma W. Senbet, 1998, Corporate governance and board effectiveness, Journal of Banking \& Finance 22, 371-403.

John, Teresa A., and Kose John, 1993, Top-management compensation and capital structure, Journal of Finance 48, 949-974.

Johnson, Shane A., Theodore Moorman, and Sorin Sorescu, 2009, A reexamination of corporate governance and equity prices, Review of Financial Studies 22, 4753-4786. 
Jun, Sang-gyung, Mookwon Jung, and Ralph Walkling, 2009, Share repurchase, executive options and wealth changes to stockholders and bondholders, Journal of Corporate Finance 15, 212-229.

Kedia, Simi, and Thomas Philippon, 2009, The cconomics of fraudulent accounting, Review of Financial Studies 22, 2169-2199.

King, Tao-Hsien Dolly, and Min-Ming Wen, 2011, Shareholder governance, bondholder governance, and managerial risk-taking, Journal of Banking \& Finance 35, 512-531.

Klock, Mark S., Sattar A. Mansi, and William F. Maxwell, 2005, Does corporate governance matter to bondholders?, Journal of Financial and Quantitative Analysis 40, 693-719.

Koppes, Richard H., Lyle G. Ganske, and Charles T. Haag, 1999, Corporate governance out of focus: The debate over classified boards, Business Lawyer 54, 1023-1055.

Krishnaswami, Sudha, and Venkat Subramanian, 1999, Information asymmetry, valuation, and the corporate spinoff decision, Journal of Financial Economics 53, 73-112.

Laeven, Luc, and Ross Levine, 2009, Bank governance, regulation, and risk taking, Journal of Financial Economics 93, 259-275.

Lehn, Kenneth, and Annette Poulsen, 1989, Free cash flow and stockholder gains in going private transactions, Journal of Finance 44, 771-787.

Levy, Haim, and Marshall Sarnat, 1970, Diversification, portfolio analysis and the uneasy case for conglomerate mergers, Journal of Finance 25, 795-802.

Lewellen, Wilbur G., 1971, A pure financial rationale for the conglomerate merger, Journal of Finance 26, 521-537.

Lorsch, Jay W., and Elizabeth MacIver, 1989. Pawns or Potentates: The Reality of America's Corporate Boards (Harvard Business School Press, Boston).

Mace, Myles L., 1986. Directors: Myth and Reality (Harvard Business School Press, Boston).

Masulis, Ronald W., Cong Wang, and Fei Xie, 2007, Corporate governance and acquirer returns, Journal of Finance 62, 1851-1889.

McNichols, Maureen F., 2002, Discussion of the quality of accruals and earnings: the role of accrual estimation errors, The Accounting Review 77, 61-69.

Murti, Bhattiprolu 2005, More boards may end staggered terms, Wall Street Journal June 8.

Myers, Stewart C., 1977, Determinants of corporate borrowing, Journal of Financial Economics 5, 147-175.

Ortiz-Molina, Hernan, 2006, Top management incentives and the pricing of corporate public debt, Journal of Financial and Quantitative Analysis 41, 317-340.

Palepu, Krishna G., 1986, Predicting takeover targets, Journal of Accounting \& Economics 8, 3-35.

Petersen, Mitchell A., 2009, Estimating standard errors in finance panel data sets: comparing approaches, Review of Financial Studies 22, 435-480.

Qiu, Jiaping, and Fan $\mathrm{Yu}, 2009$, The market for corporate control and the cost of debt, Journal of Financial Economics 93, 505-524.

Rose, Morgan J., 2009, Heterogeneous impacts of staggered boards by ownership concentration, Journal of Corporate Finance 15, 113-128.

Ryngaert, Michael, 1988, The effect of poison pill securities on shareholder wealth, Journal of Financial Economics 20,377-417.

Sengupta, Partha, 1998, Corporate disclosure quality and the cost of debt, The Accounting Review 73, 459-474.

Shastri, Kuldeep, 1990, The differential effects of mergers on corporate security values, Research in Finance 8, 179201.

Shivdasani, Anil, and David Yermack, 1999, CEO involvement in the selection of new board members: an empirical analysis, Journal of Finance 54, 1829-1853.

Smith, Clifford Jr., and Jerold Warner, 1979, On financial contracting, an analysis of bond covenants, Journal of Financial Economics 7, 117-161.

Stein, J. C., 1988, Takeover threats and managerial myopia, Journal of Political Economy 96, 61-80.

Thomas, Randall S., and James F. Cotter, 2007, Shareholder proposals in the new millennium: Shareholder support, board response, and market reaction, Journal of Corporate Finance 13, 368-391.

Vermaelen, Theo, 1981, Common stock repurchases and market signalling: an empirical study, Journal of Financial Economics 9, 139-183.

Warga, Arthur, and Ivo Welch, 1993, Bondholder losses in leveraged buyouts, Review of Financial Studies 6, 959982.

Weisbach, M. S., 1988, Outside directors and CEO turnover, Journal of Financial Economics 20, 431-460.

White, Erin, and Joann S. Lublin, 2007, Full disclosure: companies trim executive perks to avoid glare; jet rides, club dues on chopping block as SEC rules kick in, The Wall Street Journal Jan 13. 
White, Halbert, 1980, A heteroskedasticity-consistent covariance matrix estimator and a direct test for heteroskedasticity, Econometrica 48, 817-838.

Wilcox, John C., 2002, Two cheers for staggered boards, Corporate Governance Advisor 10, 1-5.

Yermack, David, 1996, Higher market valuation of companies with a small board of directors, Journal of Financial Economics 40, 185-211.

Yu, Fan, 2005, Accounting transparency and the term structure of credit spreads, Journal of Financial Economics 75, 53-84.

Zhao, Yijiang, and Kung H. Chen, 2008, Staggered boards and earnings management, The Accounting Review 83, 1347-1381.

Zhao, Yijiang, Kung H. Chen, and Lee J. Yao, 2009, Effects of takeover protection on earnings overstatements: evidence from restating firms, Review of Quantitative Finance and Accounting 33, 347-369.

Zhao, Yijiang, Kung H. Chen, and Lee J. Yao, 2009, Effects of takeover protection on earnings overstatements: evidence from restating firms, Review of Quantitative Finance and Accounting 33, 347-369. 


\section{Table 1. Summary Statistics and Correlations}

This table reports the summary statistics for the major variables used in the empirical analysis. Panel A reports the summary statistics. Panel B presents the statistics for the change of classified boards over the sample period. Panel C reports the correlations between some variables of interest. Definitions for all the variables are in the Appendix, except that Book size, Mkt size, Firm age, and Segments are the variables without taking the logs in Panel A, and $(\Delta)$ CEO compensations are reported in millions of dollars. Spread, Q, Duration, Convexity, Bond age, ROA, Book size, Mkt size, Leverage, Volatility, Mb, Capexp, CEO options, CEO shares, Inst shares, Block shares, and Earnings quality have been winsorized at the $1^{\text {st }}$ and $99^{\text {th }}$ percentiles.

\begin{tabular}{|c|c|c|c|c|c|c|}
\hline \multicolumn{7}{|c|}{ Panel A: Summary Statistics } \\
\hline Variable & Observations & $\mathrm{P} 25$ & Mean & Median & P75 & Std \\
\hline Cboard & 7,191 & 0 & 0.6 & 1 & 1 & 0.49 \\
\hline G-index & 7,191 & 7 & 9.17 & 9 & 11 & 2.54 \\
\hline Net G-index & 7,191 & 7 & 8.57 & 8 & 10 & 2.34 \\
\hline Spread (\%) & 1,467 & 1.21 & 2.61 & 1.83 & 3.11 & 2.99 \\
\hline SP_rate & 3,650 & 10 & 12.86 & 13 & 15 & 3.3 \\
\hline Q & 6,595 & 1.22 & 1.95 & 1.59 & 2.26 & 1.14 \\
\hline Duration (years) & 1,467 & 3.94 & 5.43 & 5.24 & 6.57 & 2.36 \\
\hline Convexity (years) & 1,467 & 21.41 & 51.43 & 37.64 & 63.05 & 49.15 \\
\hline Bond age (years) & 1,467 & 2.24 & 4.00 & 3.63 & 5.39 & 2.45 \\
\hline ROA & 7,143 & 0.01 & 0.02 & 0.05 & 0.08 & 0.13 \\
\hline Book size (\$millions) & 7,143 & 506.82 & $5,721.13$ & $1,188.97$ & $3,481.11$ & $24,587.37$ \\
\hline Mkt size (\$millions) & 7,128 & 553.16 & $6,784.26$ & $1,402.38$ & $4,028.89$ & $20,333.46$ \\
\hline Leverage & 7,115 & 0.05 & 0.22 & 0.2 & 0.33 & 0.19 \\
\hline Volatility & 7,190 & 0.1 & 0.15 & 0.13 & 0.19 & 0.07 \\
\hline $\mathrm{Mb}$ & 7,128 & 1.26 & 1.98 & 1.62 & 2.28 & 1.12 \\
\hline Sub debt & 7,079 & 0 & 0.1 & 0 & 0 & 0.3 \\
\hline Сарехр & 7,143 & 0.02 & 0.05 & 0.03 & 0.06 & 0.05 \\
\hline Firm age (years) & 7,190 & 9.34 & 23.09 & 15.85 & 32.61 & 18.89 \\
\hline Segments & 7,170 & 3 & 5.81 & 5 & 8 & 3.51 \\
\hline L-index & 7,191 & 0 & 0.59 & 0 & 1 & 0.89 \\
\hline CEO options & 5,387 & 0.01 & 0.36 & 0.36 & 0.60 & 0.29 \\
\hline CEO shares & 6,063 & 0 & 0.02 & 0 & 0.01 & 0.05 \\
\hline Indep director & 5,667 & 0.64 & 0.73 & 0.75 & 0.86 & 0.15 \\
\hline Board size & 5,667 & 7 & 8.97 & 9 & 10 & 2.26 \\
\hline Inst shares & 6,921 & 0.62 & 0.73 & 0.76 & 0.87 & 0.21 \\
\hline Block shares & 6,929 & 0.1 & 0.2 & 0.18 & 0.28 & 0.14 \\
\hline CEO senior & 6,089 & 0 & 0.19 & 0 & 0 & 0.39 \\
\hline CEO sole insider & 5,667 & 0 & 0.55 & 1 & 1 & 0.50 \\
\hline CEO chair & 5,025 & 0 & 0.52 & 1 & 1 & 0.50 \\
\hline CEO tenure (years) & 6,089 & 2.42 & 7.23 & 5 & 9.25 & 7.19 \\
\hline \multicolumn{7}{|c|}{ Panel B: Change of Classified Boards Over the Sample Period } \\
\hline & er of firms & Number of & lassificatic & ns Numl & er of decla & ssifications \\
\hline $2002-2003$ & & & 2 & & 7 & \\
\hline $2003-2005$ & & & 4 & & 12 & \\
\hline $2005-2007$ & & & 1 & & 39 & \\
\hline
\end{tabular}


(Table 1 continued)

Panel C: Correlations

\begin{tabular}{|c|c|c|c|c|c|c|c|c|c|c|}
\hline \multicolumn{11}{|c|}{ Panel C: Correlations } \\
\hline & Cboard & Net G-index & Spread & $\mathrm{SP}$ rate & $\mathrm{Q}$ & ROA & Book size & Mkt size & Leverage & Volatility \\
\hline Cboard & 1 & & & & & & & & & \\
\hline Net G-index & 0.31 & 1 & & & & & & & & \\
\hline Spread & -0.05 & -0.04 & 1 & & & & & & & \\
\hline $\mathrm{SP}$ rate & 0.05 & 0.09 & -0.41 & 1 & & & & & & \\
\hline $\mathrm{Q}^{-}$ & 0.00 & -0.04 & -0.24 & 0.44 & 1 & & & & & \\
\hline ROA & -0.02 & 0.02 & -0.39 & 0.45 & 0.45 & 1 & & & & \\
\hline Book size & -0.12 & -0.07 & -0.15 & 0.47 & 0.05 & 0.07 & 1 & & & \\
\hline Mkt size & -0.08 & -0.04 & -0.42 & 0.70 & 0.46 & 0.38 & 0.84 & 1 & & \\
\hline Leverage & -0.02 & -0.03 & 0.29 & -0.40 & -0.14 & -0.33 & -0.15 & -0.36 & 1 & \\
\hline Volatility & -0.09 & -0.17 & 0.37 & -0.63 & -0.20 & -0.43 & -0.27 & -0.42 & 0.28 & 1 \\
\hline
\end{tabular}




\section{Table 2. Classified Boards and the Cost of Debt}

These models present the results of pooled OLS regressions for the effect of classified boards on the cost of debt. The sample consists of S\&P 1,500 firms which do not have dual-class stocks and are not in the finance or utility industries from 2002 to 2007, and have public senior unsecured bonds. Rating dummies are generated from the Rate variable as defined in the Appendix. See the Appendix for the definitions of all other variables. All models include Fama-French 48 -industry and year dummies, and a constant term, and are not reported to save space. Standard errors are adjusted for heteroskedasticity and clustered at the firm level. t-statistics are reported in parentheses. *, **, and *** indicate significance at the $10 \%, 5 \%$, and $1 \%$ levels, respectively.

\begin{tabular}{|c|c|c|c|c|c|}
\hline Dependent variable & $\begin{array}{c}(1) \\
\text { Spread }\end{array}$ & $\begin{array}{c}(2) \\
\text { Spread }\end{array}$ & $\begin{array}{c}(3) \\
\text { Spread }\end{array}$ & $\begin{array}{c}(4) \\
\text { Spread }\end{array}$ & $\begin{array}{c}(5) \\
\text { Spread }\end{array}$ \\
\hline Cboard & $\begin{array}{c}-0.406^{* *} \\
(-2.176)\end{array}$ & $\begin{array}{c}-0.403 * * \\
(-2.072)\end{array}$ & $\begin{array}{c}-0.485^{* *} \\
(-2.396)\end{array}$ & $\begin{array}{c}-0.470 * * \\
(-2.327)\end{array}$ & $\begin{array}{c}-0.407 * * \\
(-2.238)\end{array}$ \\
\hline Net G-index & & $\begin{array}{c}-0.002 \\
(-0.058)\end{array}$ & $\begin{array}{c}0.049 \\
(1.038)\end{array}$ & $\begin{array}{c}0.066 \\
(1.342)\end{array}$ & $\begin{array}{l}0.073 * \\
(1.687)\end{array}$ \\
\hline L-index & & & $\begin{array}{c}-0.215^{* *} \\
(-2.289)\end{array}$ & $\begin{array}{c}-0.249 * * * \\
(-2.680)\end{array}$ & $\begin{array}{c}-0.227 * * * \\
(-2.637)\end{array}$ \\
\hline Duration & $\begin{array}{c}-0.417 * * * \\
(-3.603)\end{array}$ & $\begin{array}{c}-0.417 * * * \\
(-3.601)\end{array}$ & $\begin{array}{c}-0.429 * * * \\
(-3.703)\end{array}$ & $\begin{array}{c}-0.435 * * * \\
(-3.799)\end{array}$ & $\begin{array}{c}-0.405 * * * \\
(-3.567)\end{array}$ \\
\hline Convexity & $\begin{array}{c}0.004 \\
(0.849)\end{array}$ & $\begin{array}{c}0.004 \\
(0.849)\end{array}$ & $\begin{array}{c}0.005 \\
(0.929)\end{array}$ & $\begin{array}{c}0.005 \\
(0.975)\end{array}$ & $\begin{array}{c}0.004 \\
(0.819)\end{array}$ \\
\hline Bond age & $\begin{array}{c}0.221 * * * \\
(4.789)\end{array}$ & $\begin{array}{c}0.221 * * * \\
(4.829)\end{array}$ & $\begin{array}{c}0.227 * * * \\
(4.963)\end{array}$ & $\begin{array}{c}0.210^{* * *} \\
(4.543)\end{array}$ & $\begin{array}{c}0.217^{* * *} * \\
(5.046)\end{array}$ \\
\hline ROA & $\begin{array}{c}-7.725 * * * \\
(-4.281)\end{array}$ & $\begin{array}{c}-7.724 * * * \\
(-4.266)\end{array}$ & $\begin{array}{c}-7.822 * * * \\
(-4.373)\end{array}$ & $\begin{array}{c}-7.010 * * * \\
(-3.607)\end{array}$ & $\begin{array}{c}-4.939 * * \\
(-2.527)\end{array}$ \\
\hline Mkt size & $\begin{array}{c}-0.471 * * * \\
(-5.666)\end{array}$ & $\begin{array}{c}-0.472 * * * \\
(-5.725)\end{array}$ & $\begin{array}{c}-0.451 * * * \\
(-5.465)\end{array}$ & $\begin{array}{c}-0.438 * * * \\
(-4.632)\end{array}$ & $\begin{array}{c}-0.344 * * * \\
(-3.185)\end{array}$ \\
\hline Leverage & $\begin{array}{c}2.659 * * \\
(2.489)\end{array}$ & $\begin{array}{c}2.661 * * \\
(2.476)\end{array}$ & $\begin{array}{c}2.709 * * \\
(2.511)\end{array}$ & $\begin{array}{c}2.524 * * \\
(2.398)\end{array}$ & $\begin{array}{c}2.158 * * \\
(2.294)\end{array}$ \\
\hline Volatility & $\begin{array}{l}8.758^{* * *} \\
(2.491)\end{array}$ & $\begin{array}{l}8.732 * * \\
(2.456)\end{array}$ & $\begin{array}{l}8.100 * * \\
(2.290)\end{array}$ & $\begin{array}{l}9.204 * * \\
(2.574)\end{array}$ & $\begin{array}{c}5.553 \\
(1.467)\end{array}$ \\
\hline $\mathrm{Mb}$ & $\begin{array}{c}-0.026 \\
(-0.180)\end{array}$ & $\begin{array}{c}-0.026 \\
(-0.182)\end{array}$ & $\begin{array}{c}-0.040 \\
(-0.280)\end{array}$ & $\begin{array}{c}-0.079 \\
(-0.544)\end{array}$ & $\begin{array}{l}-0.211^{*} \\
(-1.656)\end{array}$ \\
\hline Sub debt & $\begin{array}{l}-0.462^{*} \\
(-1.925)\end{array}$ & $\begin{array}{l}-0.462^{*} \\
(-1.928)\end{array}$ & $\begin{array}{c}-0.499 * * \\
(-2.077)\end{array}$ & $\begin{array}{c}-0.496 * * \\
(-2.091)\end{array}$ & $\begin{array}{c}-0.668 * * * \\
(-2.893)\end{array}$ \\
\hline CEO options & & & & $\begin{array}{l}-0.638^{*} \\
(-1.837)\end{array}$ & $\begin{array}{c}-0.417 \\
(-1.220)\end{array}$ \\
\hline CEO shares & & & & $\begin{array}{c}0.165 \\
(0.043)\end{array}$ & $\begin{array}{c}1.281 \\
(0.354)\end{array}$ \\
\hline Indep director & & & & $\begin{array}{c}0.297 \\
(0.460)\end{array}$ & $\begin{array}{c}0.370 \\
(0.629)\end{array}$ \\
\hline Board size & & & & $\begin{array}{c}0.028 \\
(0.647)\end{array}$ & $\begin{array}{c}0.008 \\
(0.208)\end{array}$ \\
\hline Inst shares & & & & $\begin{array}{c}-2.893 * * * \\
(-2.733)\end{array}$ & $\begin{array}{c}-2.304 * * \\
(-2.071)\end{array}$ \\
\hline Block shares & & & & $\begin{array}{l}1.954^{*} \\
(1.954)\end{array}$ & $\begin{array}{l}1.629^{*} \\
(1.721)\end{array}$ \\
\hline
\end{tabular}


(Table 2 continued)

\begin{tabular}{|c|c|c|c|c|c|}
\hline Rate2 & & & & & $\begin{array}{c}-9.723 * * \\
(-2.193)\end{array}$ \\
\hline Rate3 & & & & & $\begin{array}{c}-10.023 * * \\
(-2.285)\end{array}$ \\
\hline Rate4 & & & & & $\begin{array}{c}-10.944 * * \\
(-2.459)\end{array}$ \\
\hline Rate5 & & & & & $\begin{array}{c}-11.007 * * \\
(-2.472)\end{array}$ \\
\hline Rate6 & & & & & $\begin{array}{c}-10.063 * * \\
(-2.256)\end{array}$ \\
\hline Rate7 & & & & & $\begin{array}{c}-9.856^{* *} \\
(-2.199)\end{array}$ \\
\hline Observations & 1,467 & 1,467 & 1,467 & 1,467 & 1,467 \\
\hline Adjusted $\mathrm{R}^{2}$ & 0.37 & 0.37 & 0.38 & 0.39 & 0.42 \\
\hline
\end{tabular}




\section{Table 3. Test of Antitakeover Hypothesis}

These models present the results of pooled OLS regressions to test the hypothesis that the negative effect of classified boards on the cost of debt is driven by their antitakeover effect. The sample consists of S\&P 1,500 firms which do not have dual-class stocks and are not in the finance or utility industries from 2002 to 2007, and have public senior unsecured bonds. Poison pill is a dummy variable that equals one if the firm has a poison pill in place, and zero otherwise. Target is a dummy variable that equals one if the firm was a takeover target between 2002 and 2007. Protection is the weighted average of the dummy variables indicating whether an issue has one of the eventrisk covenants as defined in Cremers, Nair, and Wei (2007), and across different issues of the firm at a given year, where the weight on an issue is the issue size as a percentage of the aggregate issue sizes of the firm in a given year. Maturity is the weighted average maturity of the outstanding bonds of a firm in the sample in a given year, with the weight being the issue size of the bond as a percentage of the total issue sizes of the firm in a given year. Long maturity is a dummy variable that equals one if the maturity of the bonds of a firm is above the sample median, and zero otherwise. No cboard is a dummy variable that equals one if the board is not classified, and zero otherwise. State_vul is a state-level takeover vulnerability index based on the statutes in Francis, Hasan, John and Waisman (2010). It is formed by subtracting the state-level antitakeover index from 5, where the index is the sum of the indicators for the five antitakeover laws: business combination, control share acquisition, fair price, constituencies and poison pill endorsement. State_G is another state-level takeover vulnerability index based on the statutes in the components of the G-index. It is formed by subtracting the state-level antitakeover index from 6 , where the index is the sum of the indicators for the six antitakeover laws: business combination, control share acquisition, fair price, constituencies, antigreenmail and control-share cash-out. See the Appendix for the definitions of other variables. All models include Fama-French 48-industry and year dummies, and a constant term, and are not reported to save space. Standard errors are adjusted for heteroskedasticity and clustered at the firm level. t-statistics are reported in parentheses. *,**, and $* * *$ indicate significance at the $10 \%, 5 \%$, and $1 \%$ levels, respectively.

\begin{tabular}{|c|c|c|c|c|c|c|}
\hline Dependent variable & $\begin{array}{c}(1) \\
\text { Spread }\end{array}$ & $\begin{array}{c}(2) \\
\text { Spread } \\
\end{array}$ & $\begin{array}{c}(3) \\
\text { Spread }\end{array}$ & $\begin{array}{c}(4) \\
\text { Spread } \\
\end{array}$ & $\begin{array}{c}(5) \\
\text { Spread } \\
\end{array}$ & $\begin{array}{c}(6) \\
\text { Spread } \\
\end{array}$ \\
\hline Cboard & $\begin{array}{l}-0.398^{*} \\
(-1.908)\end{array}$ & $\begin{array}{c}-0.420 * * \\
(-2.285)\end{array}$ & $\begin{array}{l}-0.395^{*} \\
(-1.905)\end{array}$ & $\begin{array}{c}-0.444 * * \\
(-2.006)\end{array}$ & $\begin{array}{l}-0.540 * * \\
(-2.132)\end{array}$ & $\begin{array}{l}-0.630 * \\
(-1.702)\end{array}$ \\
\hline Cboard * Poison pill & $\begin{array}{c}-0.013 \\
(-0.066)\end{array}$ & & & & & \\
\hline Cboard * Target & & $\begin{array}{c}0.083 \\
(0.307)\end{array}$ & & & & \\
\hline Protection * Cboard & & & $\begin{array}{c}-0.046 \\
(-0.081)\end{array}$ & & & \\
\hline Protection & & & $\begin{array}{c}0.470 \\
(0.984)\end{array}$ & & & \\
\hline Cboard * Long maturity & & & & $\begin{array}{c}0.282 \\
(1.374)\end{array}$ & & \\
\hline Maturity & & & & $\begin{array}{c}0.181 * * \\
(2.167)\end{array}$ & & \\
\hline No_cboard * State_vul & & & & & $\begin{array}{c}-0.032 \\
(-0.373)\end{array}$ & \\
\hline State_vul & & & & & $\begin{array}{c}0.080 \\
(1.635)\end{array}$ & \\
\hline No_cboard * State_G & & & & & & $\begin{array}{c}-0.046 \\
(-0.481)\end{array}$ \\
\hline State_G & & & & & & $\begin{array}{l}0.086^{*} \\
(1.714)\end{array}$ \\
\hline
\end{tabular}


(Table 3 continued)

\begin{tabular}{|c|c|c|c|c|c|c|}
\hline Net G-index & $\begin{array}{c}0.074 \\
(1.625)\end{array}$ & $\begin{array}{c}0.074 * \\
(1.702)\end{array}$ & $\begin{array}{c}0.044 \\
(0.867)\end{array}$ & $\begin{array}{c}0.057 \\
(1.381)\end{array}$ & $\begin{array}{c}0.089 * \\
(1.814)\end{array}$ & $\begin{array}{c}0.090 * \\
(1.778)\end{array}$ \\
\hline L-index & $\begin{array}{c}-0.227 * * * \\
(-2.635)\end{array}$ & $\begin{array}{c}-0.226 * * * \\
(-2.634)\end{array}$ & $\begin{array}{c}-0.099 \\
(-1.020)\end{array}$ & $\begin{array}{c}-0.193 * * \\
(-2.337)\end{array}$ & $\begin{array}{c}-0.241 * * * \\
(-2.688)\end{array}$ & $\begin{array}{c}-0.243 * * * \\
(-2.655)\end{array}$ \\
\hline Duration & $\begin{array}{c}-0.405 * * * \\
(-3.514)\end{array}$ & $\begin{array}{c}-0.405 * * * \\
(-3.577)\end{array}$ & $\begin{array}{c}-0.499 * * * \\
(-3.730)\end{array}$ & $\begin{array}{c}-0.656 * * * \\
(-4.232)\end{array}$ & $\begin{array}{c}-0.413 * * * \\
(-3.584)\end{array}$ & $\begin{array}{c}-0.412 * * * \\
(-3.567)\end{array}$ \\
\hline Convexity & $\begin{array}{c}0.004 \\
(0.806)\end{array}$ & $\begin{array}{c}0.004 \\
(0.817)\end{array}$ & $\begin{array}{c}0.014 * * \\
(2.034)\end{array}$ & $\begin{array}{c}-0.001 \\
(-0.219)\end{array}$ & $\begin{array}{c}0.004 \\
(0.874)\end{array}$ & $\begin{array}{c}0.004 \\
(0.868)\end{array}$ \\
\hline Bond age & $\begin{array}{c}0.217 * * * \\
(5.066)\end{array}$ & $\begin{array}{c}0.216^{* * *} * \\
(5.053)\end{array}$ & $\begin{array}{c}0.172 * * * \\
(2.751)\end{array}$ & $\begin{array}{c}0.152 * * * \\
(3.470)\end{array}$ & $\begin{array}{c}0.217 * * * \\
(5.125)\end{array}$ & $\begin{array}{c}0.216^{* * *} \\
(5.136)\end{array}$ \\
\hline ROA & $\begin{array}{c}-4.939 * * \\
(-2.527)\end{array}$ & $\begin{array}{c}-4.917 * * \\
(-2.504)\end{array}$ & $\begin{array}{c}-5.485 * * * \\
(-2.823)\end{array}$ & $\begin{array}{c}-5.075 * * * \\
(-2.636)\end{array}$ & $\begin{array}{c}-4.866^{* *} \\
(-2.495)\end{array}$ & $\begin{array}{c}-4.888^{* *} \\
(-2.507)\end{array}$ \\
\hline Mkt size & $\begin{array}{c}-0.345 * * * \\
(-3.163)\end{array}$ & $\begin{array}{c}-0.346 * * * \\
(-3.203)\end{array}$ & $\begin{array}{c}-0.443 * * * \\
(-3.056)\end{array}$ & $\begin{array}{c}-0.372 * * * \\
(-3.586)\end{array}$ & $\begin{array}{c}-0.344 * * * \\
(-3.234)\end{array}$ & $\begin{array}{c}-0.343 * * * \\
(-3.236)\end{array}$ \\
\hline Leverage & $\begin{array}{c}2.158 * * \\
(2.293)\end{array}$ & $\begin{array}{l}2.158 * * \\
(2.292)\end{array}$ & $\begin{array}{c}1.424 \\
(1.265)\end{array}$ & $\begin{array}{l}2.033 * * \\
(2.212)\end{array}$ & $\begin{array}{l}2.161 * * \\
(2.283)\end{array}$ & $\begin{array}{l}2.168 * * \\
(2.265)\end{array}$ \\
\hline Volatility & $\begin{array}{c}5.542 \\
(1.451)\end{array}$ & $\begin{array}{c}5.545 \\
(1.467)\end{array}$ & $\begin{array}{c}4.187 \\
(1.016)\end{array}$ & $\begin{array}{c}5.918 \\
(1.627)\end{array}$ & $\begin{array}{c}5.379 \\
(1.424)\end{array}$ & $\begin{array}{c}5.420 \\
(1.434)\end{array}$ \\
\hline $\mathrm{Mb}$ & $\begin{array}{c}-0.211 \\
(-1.648)\end{array}$ & $\begin{array}{c}-0.209 \\
(-1.645)\end{array}$ & $\begin{array}{c}-0.154 \\
(-1.043)\end{array}$ & $\begin{array}{c}-0.160 \\
(-1.264)\end{array}$ & $\begin{array}{l}-0.216^{*} \\
(-1.674)\end{array}$ & $\begin{array}{l}-0.215^{*} \\
(-1.672)\end{array}$ \\
\hline Sub debt & $\begin{array}{c}-0.667 * * * \\
(-2.887)\end{array}$ & $\begin{array}{c}-0.672 * * * \\
(-2.913)\end{array}$ & $\begin{array}{c}-0.649 * * \\
(-2.287)\end{array}$ & $\begin{array}{c}-0.645 * * * \\
(-2.896)\end{array}$ & $\begin{array}{c}-0.653 * * * \\
(-2.844)\end{array}$ & $\begin{array}{c}-0.656 * * * \\
(-2.866)\end{array}$ \\
\hline CEO options & $\begin{array}{c}-0.417 \\
(-1.219)\end{array}$ & $\begin{array}{c}-0.418 \\
(-1.219)\end{array}$ & $\begin{array}{c}-0.883 * * \\
(-2.343)\end{array}$ & $\begin{array}{c}-0.383 \\
(-1.153)\end{array}$ & $\begin{array}{c}-0.419 \\
(-1.230)\end{array}$ & $\begin{array}{c}-0.417 \\
(-1.221)\end{array}$ \\
\hline CEO shares & $\begin{array}{c}1.260 \\
(0.348)\end{array}$ & $\begin{array}{c}1.293 \\
(0.358)\end{array}$ & $\begin{array}{c}2.102 \\
(0.509)\end{array}$ & $\begin{array}{c}1.371 \\
(0.388)\end{array}$ & $\begin{array}{c}1.418 \\
(0.390)\end{array}$ & $\begin{array}{c}1.365 \\
(0.375)\end{array}$ \\
\hline Indep director & $\begin{array}{c}0.373 \\
(0.626)\end{array}$ & $\begin{array}{c}0.376 \\
(0.642)\end{array}$ & $\begin{array}{c}0.346 \\
(0.468)\end{array}$ & $\begin{array}{c}0.339 \\
(0.582)\end{array}$ & $\begin{array}{c}0.376 \\
(0.638)\end{array}$ & $\begin{array}{c}0.372 \\
(0.630)\end{array}$ \\
\hline Board size & $\begin{array}{c}0.008 \\
(0.204)\end{array}$ & $\begin{array}{c}0.008 \\
(0.211)\end{array}$ & $\begin{array}{c}0.032 \\
(0.863)\end{array}$ & $\begin{array}{c}0.005 \\
(0.139)\end{array}$ & $\begin{array}{c}0.012 \\
(0.310)\end{array}$ & $\begin{array}{c}0.011 \\
(0.301)\end{array}$ \\
\hline Inst shares & $\begin{array}{c}-2.306^{* *} \\
(-2.061)\end{array}$ & $\begin{array}{c}-2.335^{* *} \\
(-2.056)\end{array}$ & $\begin{array}{c}-1.639 \\
(-1.174)\end{array}$ & $\begin{array}{l}-2.133^{*} \\
(-1.945)\end{array}$ & $\begin{array}{l}-2.354 * * \\
(-2.112)\end{array}$ & $\begin{array}{c}-2.350 * * \\
(-2.109)\end{array}$ \\
\hline Block shares & $\begin{array}{c}1.627^{*} \\
(1.725)\end{array}$ & $\begin{array}{c}1.625^{*} \\
(1.719)\end{array}$ & $\begin{array}{l}2.029 * \\
(1.912)\end{array}$ & $\begin{array}{c}1.476 \\
(1.626)\end{array}$ & $\begin{array}{l}1.638 * \\
(1.739)\end{array}$ & $\begin{array}{c}1.622 * \\
(1.724)\end{array}$ \\
\hline Rate2 & $\begin{array}{c}-9.721^{* *} \\
(-2.193)\end{array}$ & $\begin{array}{c}-9.728 * * \\
(-2.193)\end{array}$ & $\begin{array}{c}-3.957 * * * \\
(-2.812)\end{array}$ & $\begin{array}{c}-9.559 * * \\
(-2.269)\end{array}$ & $\begin{array}{c}-9.636 * * \\
(-2.174)\end{array}$ & $\begin{array}{c}-9.649 * * \\
(-2.174)\end{array}$ \\
\hline Rate3 & $\begin{array}{c}-10.022 * * \\
(-2.284)\end{array}$ & $\begin{array}{c}-10.026^{* *} \\
(-2.284)\end{array}$ & $\begin{array}{c}-4.598 * * * \\
(-3.115)\end{array}$ & $\begin{array}{c}-9.892 * * \\
(-2.376)\end{array}$ & $\begin{array}{c}-9.957 * * \\
(-2.268)\end{array}$ & $\begin{array}{c}-9.966 * * \\
(-2.268)\end{array}$ \\
\hline Rate4 & $\begin{array}{c}-10.944 * * \\
(-2.459)\end{array}$ & $\begin{array}{c}-10.945^{* *} \\
(-2.458)\end{array}$ & $\begin{array}{c}-5.143 * * * \\
(-3.248)\end{array}$ & $\begin{array}{c}-10.693 * * \\
(-2.537)\end{array}$ & $\begin{array}{c}-10.885^{* *} \\
(-2.447)\end{array}$ & $\begin{array}{c}-10.890 * * \\
(-2.446)\end{array}$ \\
\hline Rate5 & $\begin{array}{c}-11.006 * * \\
(-2.472)\end{array}$ & $\begin{array}{c}-11.010^{* *} \\
(-2.472)\end{array}$ & $\begin{array}{c}-5.234 * * * \\
(-3.200)\end{array}$ & $\begin{array}{c}-10.805 * * \\
(-2.562)\end{array}$ & $\begin{array}{c}-10.955^{* *} \\
(-2.461)\end{array}$ & $\begin{array}{c}-10.952 * * \\
(-2.458)\end{array}$ \\
\hline Rate6 & $\begin{array}{c}-10.061 * * \\
(-2.256)\end{array}$ & $\begin{array}{c}-10.069 * * \\
(-2.256)\end{array}$ & $\begin{array}{c}-4.693 * * * \\
(-2.608)\end{array}$ & $\begin{array}{c}-9.863 * * \\
(-2.336)\end{array}$ & $\begin{array}{c}-10.026^{* *} \\
(-2.248)\end{array}$ & $\begin{array}{c}-10.018 * * \\
(-2.244)\end{array}$ \\
\hline Rate7 & $\begin{array}{c}-9.854 * * \\
(-2.199)\end{array}$ & $\begin{array}{c}-9.855 * * \\
(-2.197)\end{array}$ & $\begin{array}{c}-4.114 * * \\
(-2.132)\end{array}$ & $\begin{array}{c}-9.771 * * \\
(-2.299)\end{array}$ & $\begin{array}{c}-9.825^{* *} \\
(-2.198)\end{array}$ & $\begin{array}{c}-9.826^{* *} \\
(-2.197)\end{array}$ \\
\hline $\begin{array}{l}\text { Observations } \\
\text { Adjusted } \mathrm{R}^{2}\end{array}$ & $\begin{array}{c}1,467 \\
0.42\end{array}$ & $\begin{array}{c}1,467 \\
0.42\end{array}$ & $\begin{array}{c}1,091 \\
0.43\end{array}$ & $\begin{array}{c}1,467 \\
0.44\end{array}$ & $\begin{array}{c}1,467 \\
0.42\end{array}$ & $\begin{array}{c}1,467 \\
0.42\end{array}$ \\
\hline
\end{tabular}




\section{Table 4. Classified Boards and Risk-taking}

These models use Glejser's (1969) two-step heteroskedasticity tests to examine the relation between classified boards and the risk-taking of managers. Only the second-step results are reported. The samples consist of S\&P 1,500 non-dual-class, non-finance, and non-utility firms from 2002 to 2007. In the first step of Model 1, I run the following Fama-French three-factor model for monthly stock returns:

$r-r_{f}=\beta_{1}\left(r_{m}-r_{f}\right)+\beta_{2} S M B+\beta_{3} H M L+$ residuals, where $r$ is the monthly stock return, $r_{f}$ is the risk-free rate, $r_{m}$ is the value-weighted market return, $S M B$ is the difference between the returns of small-firms and big-firms, $H M L$ is the difference between the returns of high book-to-market firms and low book-to-market firms. In the second step, I run the regression on the absolute values of the residuals from the first-step model: $\mid$ residuals $\mid=\alpha_{1}$ *classified board $+\overline{\text { control variables }} \overline{\alpha_{2}}+\alpha_{0}+\varepsilon$. Control variables include the Net G-index, board size and independence, the three CEO power variables, CEO share holdings, CEO tenure, ROA, firm size, capital expenditure, leverage, firm age, number of business segments, year dummies, and Fama-French 48-industry dummies. For Model 2 (3) I run the following regression for Tobin's Q (ROA) in the first step: $Q(R O A)=\alpha_{1} *$ classified board $+\overline{\text { control variables }} \overline{\alpha_{2}}+\alpha_{0}+$ residuals, where the control variables follow those of the regression of the stock return residuals, except that in the ROA regression I do not control for ROA. I then run regressions on the absolute values of the residuals from these two regression models with the same controls as the regression model on stock return residuals above. All models include Fama-French 48-industry and year dummies, and a constant term, and are not reported to save space. See the Appendix for the definitions of the variables. Standard errors are adjusted for heteroskedasticity and clustered at the firm level. t-statistics are reported in parentheses. *, $* *$, and $* * *$ indicate significance at the $10 \%, 5 \%$, and $1 \%$ levels, respectively.

(1)

\begin{tabular}{lccc} 
Dependent variable & $\begin{array}{c}\text { Absolute value of stock } \\
\text { return residuals }\end{array}$ & $\begin{array}{c}\text { Absolute value of Tobin's } \\
\text { Q residuals }\end{array}$ & $\begin{array}{c}\text { Absolute value of ROA } \\
\text { residuals }\end{array}$ \\
\hline \multirow{3}{*}{ Cboard } & & & \\
& $-0.003^{* *}$ & $-0.146^{* * *}$ & -0.004 \\
Net G-index & $-2.570)$ & $(-3.883)$ & $(-1.146)$ \\
& $-0.001^{* * *}$ & 0.001 & $-0.001^{*}$ \\
ROA & $(-2.750)$ & $(0.107)$ & $(-1.742)$ \\
& $-0.123^{* * *}$ & -0.055 & $-0.460^{* * *}$ \\
Indep director & $(-15.429)$ & $(-0.165)$ & $(-14.254)$ \\
& -0.003 & 0.138 & 0.014 \\
Board size & $-0.623)$ & $(1.238)$ & $(1.521)$ \\
& $-0.001^{* *}$ & $-0.018^{* * *}$ & -0.000 \\
Book size & $(-2.033)$ & $(-2.201)$ & $(-0.420)$ \\
& $-0.005^{* * *}$ & $-0.043^{* * *}$ & $-0.005^{* * *}$ \\
CEO senior & $(-10.050)$ & $(-2.633)$ & $(-3.388)$ \\
& 0.000 & 0.055 & 0.001 \\
CEO sole insider & $(0.062)$ & $(0.960)$ & $(0.265)$ \\
& 0.001 & $-0.110^{* * *}$ & -0.004 \\
CEO chair & $(0.647)$ & $(-3.519)$ & $(-1.366)$ \\
& 0.000 & -0.014 & 0.002 \\
CEO shares & $(0.267)$ & $(-0.513)$ & $(0.891)$ \\
& 0.012 & -0.670 & 0.003 \\
CEO tenure & $(0.740)$ & $(-1.591)$ & $(0.082)$ \\
& 0.000 & 0.003 & -0.000 \\
& $(0.271)$ & $(1.024)$ & $(-1.551)$ \\
\hline
\end{tabular}


(Table 4 continued)

\begin{tabular}{lccc}
\hline Capexp & $0.031^{*}$ & $1.203 * * *$ & $0.076^{* *}$ \\
& $(1.931)$ & $(2.690)$ & $(2.359)$ \\
Leverage & $0.010^{* *}$ & -0.167 & -0.019 \\
& $(2.463)$ & $(-1.064)$ & $(-1.303)$ \\
Firm age & $-0.004 * * *$ & -0.021 & -0.003 \\
& $(-4.607)$ & $(-0.754)$ & $(-1.453)$ \\
Segments & 0.001 & $-0.047 *$ & -0.002 \\
Observations & $(0.677)$ & $(-1.678)$ & $(-0.790)$ \\
Adjusted R & 54,506 & 4,232 & 4,620 \\
\hline
\end{tabular}




\section{Table 5. The Differential Effects of Classified Boards on the Cost of Debt Conditional on Agency Conflict between Shareholders and Bondholders}

These models present the results of pooled OLS regressions for the differential effect of classified boards on the cost of debt, conditional on the expected divergence of interests between shareholders and bondholders. The sample consists of S\&P 1,500 firms which do not have dual-class stocks and are not in the finance or utility industries from 2002 to 2007, and have public senior unsecured bonds. High leverage is a dummy variable that equals one if the firm's leverage is greater than the median value in the sample, and zero otherwise. SPC is a dummy variable that equals one if the firm's S\&P credit rating is speculative-grade (below BBB-), and zero otherwise. Rating dummies are generated from the Rate variable as defined in the Appendix. See the Appendix for the definitions of other variables. All models include Fama-French 48-industry and year dummies, and a constant term, and are not reported to save space. Standard errors are adjusted for heteroskedasticity and clustered at the firm level. t-statistics are reported in parentheses. $*, * *$, and $* * *$ indicate significance at the $10 \%, 5 \%$, and $1 \%$ levels, respectively.

\begin{tabular}{|c|c|c|c|c|c|c|}
\hline Dependent variable & $\begin{array}{c}(1) \\
\text { Spread }\end{array}$ & $\begin{array}{c}(2) \\
\text { Spread }\end{array}$ & $\begin{array}{c}(3) \\
\text { Spread }\end{array}$ & $\begin{array}{c}(4) \\
\text { Spread }\end{array}$ & $\begin{array}{c}(5) \\
\text { Spread } \\
\end{array}$ & $\begin{array}{c}(6) \\
\text { Spread } \\
\end{array}$ \\
\hline Sample & $\begin{array}{c}\text { High } \\
\text { leverage }=1\end{array}$ & $\begin{array}{c}\text { High } \\
\text { leverage }=0\end{array}$ & $\mathrm{SPC}=1$ & $\mathrm{SPC}=0$ & $\begin{array}{c}\text { High leverage * } \\
\mathrm{SPC}=1\end{array}$ & $\begin{array}{c}\text { High leverage * } \\
\text { SPC }=0\end{array}$ \\
\hline p-value for Chow test & \multicolumn{2}{|c|}{0.483} & \multicolumn{2}{|c|}{$0.046^{* *}$} & \multicolumn{2}{|c|}{$0.081^{*}$} \\
\hline Cboard & $\begin{array}{l}-0.490^{*} \\
(-1.726)\end{array}$ & $\begin{array}{c}-0.238 \\
(-1.037)\end{array}$ & $\begin{array}{c}-1.234 * * \\
(-2.021)\end{array}$ & $\begin{array}{c}-0.042 \\
(-0.302)\end{array}$ & $\begin{array}{l}-1.029 * \\
(-1.783)\end{array}$ & $\begin{array}{c}-0.069 \\
(-0.460)\end{array}$ \\
\hline Net G-index & $\begin{array}{c}0.086 \\
(1.425)\end{array}$ & $\begin{array}{c}0.043 \\
(0.773)\end{array}$ & $\begin{array}{c}0.142 \\
(0.856)\end{array}$ & $\begin{array}{c}0.049 \\
(1.212)\end{array}$ & $\begin{array}{c}0.242 \\
(1.305)\end{array}$ & $\begin{array}{c}0.052 \\
(1.258)\end{array}$ \\
\hline L-index & $\begin{array}{c}-0.164 \\
(-1.253)\end{array}$ & $\begin{array}{l}-0.202^{*} \\
(-1.689)\end{array}$ & $\begin{array}{c}-0.585 * * * \\
(-2.672)\end{array}$ & $\begin{array}{c}-0.036 \\
(-0.425)\end{array}$ & $\begin{array}{c}-0.524 * * \\
(-2.174)\end{array}$ & $\begin{array}{c}-0.096 \\
(-1.094)\end{array}$ \\
\hline Duration & $\begin{array}{c}-0.520 * * \\
(-2.511)\end{array}$ & $\begin{array}{c}-0.330 * * \\
(-2.488)\end{array}$ & $\begin{array}{c}-0.237 \\
(-0.818)\end{array}$ & $\begin{array}{c}-0.434 * * * \\
(-3.312)\end{array}$ & $\begin{array}{c}-0.029 \\
(-0.089)\end{array}$ & $\begin{array}{c}-0.433 * * * \\
(-3.565)\end{array}$ \\
\hline Convexity & $\begin{array}{c}0.003 \\
(0.354)\end{array}$ & $\begin{array}{c}0.004 \\
(0.677)\end{array}$ & $\begin{array}{c}-0.017 \\
(-1.282)\end{array}$ & $\begin{array}{c}0.008 \\
(1.372)\end{array}$ & $\begin{array}{c}-0.030 * * \\
(-2.288)\end{array}$ & $\begin{array}{c}0.008 \\
(1.410)\end{array}$ \\
\hline Bond age & $\begin{array}{c}0.233 * * * \\
(3.307)\end{array}$ & $\begin{array}{c}0.175 * * * \\
(3.314)\end{array}$ & $\begin{array}{c}0.187 \\
(1.582)\end{array}$ & $\begin{array}{c}0.179 * * * \\
(4.803)\end{array}$ & $\begin{array}{c}0.345 * * * \\
(2.778)\end{array}$ & $\begin{array}{c}0.168 * * * \\
(4.669)\end{array}$ \\
\hline ROA & $\begin{array}{l}-4.885^{*} \\
(-1.763)\end{array}$ & $\begin{array}{l}-2.887 \\
(-1.463)\end{array}$ & $\begin{array}{l}-5.020^{*} \\
(-1.820)\end{array}$ & $\begin{array}{c}-0.919 \\
(-0.683)\end{array}$ & $\begin{array}{c}-5.485 \\
(-1.588)\end{array}$ & $\begin{array}{c}-1.886 \\
(-1.226)\end{array}$ \\
\hline Mkt size & $\begin{array}{c}-0.334 * * \\
(-2.138)\end{array}$ & $\begin{array}{c}-0.375 * * \\
(-2.049)\end{array}$ & $\begin{array}{c}-0.272 \\
(-0.737)\end{array}$ & $\begin{array}{l}-0.147^{*} \\
(-1.917)\end{array}$ & $\begin{array}{c}-0.053 \\
(-0.151)\end{array}$ & $\begin{array}{c}-0.298 * * * \\
(-2.709)\end{array}$ \\
\hline Leverage & $\begin{array}{l}3.768 * * \\
(2.308)\end{array}$ & $\begin{array}{l}1.109 \\
(0.503)\end{array}$ & $\begin{array}{l}2.176 \\
(0.563)\end{array}$ & $\begin{array}{c}1.849 * * * \\
(3.371)\end{array}$ & $\begin{array}{l}9.938^{* *} \\
(2.182)\end{array}$ & $\begin{array}{l}1.482 * * \\
(2.323)\end{array}$ \\
\hline Volatility & $\begin{array}{l}2.914 \\
(0.570)\end{array}$ & $\begin{array}{l}8.787^{*} \\
(1.830)\end{array}$ & $\begin{array}{l}10.971 \\
(1.297)\end{array}$ & $\begin{array}{c}4.446 \\
(1.470)\end{array}$ & $\begin{array}{l}3.797 \\
(0.541)\end{array}$ & $\begin{array}{l}7.415^{*} \\
(1.961)\end{array}$ \\
\hline $\mathrm{Mb}$ & $\begin{array}{c}-0.535 * * \\
(-2.414)\end{array}$ & $\begin{array}{c}-0.243 * * \\
(-2.184)\end{array}$ & $\begin{array}{l}-1.123 * * \\
(-2.225)\end{array}$ & $\begin{array}{c}-0.230 * * \\
(-2.586)\end{array}$ & $\begin{array}{c}-1.669 * * \\
(-2.252)\end{array}$ & $\begin{array}{l}-0.221 * * \\
(-2.429)\end{array}$ \\
\hline Sub debt & $\begin{array}{c}-1.062 * * * \\
(-2.981)\end{array}$ & $\begin{array}{c}0.059 \\
(0.195)\end{array}$ & $\begin{array}{c}-1.161 * * \\
(-2.123)\end{array}$ & $\begin{array}{c}-0.059 \\
(-0.289)\end{array}$ & $\begin{array}{c}-1.917 * * * \\
(-2.696)\end{array}$ & $\begin{array}{c}-0.049 \\
(-0.244)\end{array}$ \\
\hline CEO options & $\begin{array}{c}0.009 \\
(0.014)\end{array}$ & $\begin{array}{c}-0.722 * * \\
(-2.026)\end{array}$ & $\begin{array}{c}-0.278 \\
(-0.273)\end{array}$ & $\begin{array}{c}-0.486 * * \\
(-2.006)\end{array}$ & $\begin{array}{c}0.206 \\
(0.158)\end{array}$ & $\begin{array}{c}-0.586 * * \\
(-2.279)\end{array}$ \\
\hline CEO shares & $\begin{array}{c}3.525 \\
(0.742)\end{array}$ & $\begin{array}{c}-2.224 \\
(-0.412)\end{array}$ & $\begin{array}{c}-0.904 \\
(-0.155)\end{array}$ & $\begin{array}{c}3.568 \\
(1.029)\end{array}$ & $\begin{array}{c}2.877 \\
(0.468)\end{array}$ & $\begin{array}{c}-0.684 \\
(-0.180)\end{array}$ \\
\hline Indep director & $\begin{array}{l}1.747^{*} \\
(1.875)\end{array}$ & $\begin{array}{c}-0.828 \\
(-1.178)\end{array}$ & $\begin{array}{c}2.193 \\
(1.031)\end{array}$ & $\begin{array}{c}0.268 \\
(0.578)\end{array}$ & $\begin{array}{c}2.260 \\
(1.026)\end{array}$ & $\begin{array}{c}-0.008 \\
(-0.015)\end{array}$ \\
\hline
\end{tabular}

(continued) 


\begin{tabular}{lcccccc}
\multicolumn{7}{c}{ (Table 5 continued) } \\
\hline Board size & -0.003 & 0.021 & -0.139 & 0.019 & -0.050 & 0.015 \\
& $(-0.053)$ & $(0.537)$ & $(-1.130)$ & $(0.603)$ & $(-0.395)$ & $(0.469)$ \\
Inst shares & $-2.733^{*}$ & -2.875 & $-4.996^{* *}$ & -0.619 & -2.725 & -1.946 \\
& $(-1.835)$ & $(-1.638)$ & $(-2.027)$ & $(-0.796)$ & $(-1.184)$ & $(-1.513)$ \\
Block shares & $2.994^{* *}$ & 0.601 & $5.018^{* *}$ & 0.410 & $4.317^{*}$ & 0.839 \\
& $(2.181)$ & $(0.487)$ & $(2.380)$ & $(0.501)$ & $(1.837)$ & $(0.944)$ \\
Rate2 & $-10.603^{*}$ & $-6.667^{* * *}$ & -7.154 & & -6.779 & $-6.362^{* * *}$ \\
& $(-1.676)$ & $(-4.823)$ & $(-1.554)$ & & $(-1.023)$ & $(-5.645)$ \\
Rate3 & $-11.061^{*}$ & $-6.519^{* * *}$ & -7.383 & & -7.302 & $-6.302^{* * *}$ \\
& $(-1.751)$ & $(-4.655)$ & $(-1.592)$ & & $(-1.088)$ & $(-6.563)$ \\
Rate4 & $-11.940^{*}$ & $-7.353^{* * *}$ & & -0.151 & & $-7.303^{* * *}$ \\
& $(-1.863)$ & $(-5.217)$ & & $(-0.291)$ & & $(-8.408)$ \\
Rate5 & $-12.219^{*}$ & $-7.369^{* * *}$ & & -0.467 & & $-7.494^{* * *}$ \\
& $(-1.899)$ & $(-4.827)$ & & $(-0.978)$ & & $-(-8.326)$ \\
Rate6 & $-11.090^{*}$ & $-6.757^{* * *}$ & & 0.006 & & $-6.826^{* * *}$ \\
& $(-1.719)$ & $(-3.876)$ & & $(0.012)$ & & $(-6.544)$ \\
Rate7 & $-11.662^{*}$ & $-6.243^{* * *}$ & & 0.000 & & $-6.732^{* * *}$ \\
& $(-1.801)$ & $(-3.442)$ & & $()$. & & $(-5.702)$ \\
Observations & 734 & 733 & 354 & 1,113 & 257 & 1,210 \\
Adjusted R & 0.47 & 0.31 & 0.50 & 0.23 & 0.54 & 0.29 \\
\hline
\end{tabular}




\section{Table 6. Classified Boards and Financial Transparency}

These models test the effect of classified boards on a firm's financial transparency. The samples consist of S\&P 1,500 non-dual-class, non-finance, and non-utility firms from 2002 to 2007. Models 1 and 2 use OLS model. Model 3 uses probit model. Firm-years that experienced a change in the classification status are deleted from the sample. See the Appendix for the definitions of the variables. All models include Fama-French 48-industry and year dummies, and a constant term, and are not reported to save space. Standard errors are adjusted for heteroskedasticity and clustered at the firm level. t-statistics are reported in parentheses. *, **, and *** indicate significance at the $10 \%, 5 \%$, and $1 \%$ levels, respectively.

(1) Earnings quality

Dependent variable

Cboard

Net G-index

Mkt size

Operating cycle

Sigma_cfo

Sigma_sales

Negative earnings

ROA

Volatility

CEO senior

CEO sole insider

CEO chair

CEO shares

CEO tenure

Indep director

Board size

Inst shares

Block shares
$0.051 * * *$

(3.137)

0.000

$(0.103)$

$-0.034 * * *$

$(-5.538)$

$-0.028^{*}$

$(-1.946)$

0.033

$(0.132)$

$-0.038$

$(-0.811)$

$-0.217^{* * * *}$

$(-3.194)$

$0.563 * * *$

(5.073)

$-2.233^{* * *}$

$(-9.042)$

$-0.021$

$(-0.804)$

0.011

$(0.754)$

0.005

$(0.368)$

0.232

(1.320)

$-0.000$

$(-0.152)$

$-0.006$

$(-0.123)$

$-0.002$

$(-0.456)$

$0.157^{* * *}$

(2.588)

$-0.185^{* * *}$
(2)

(3)

Analyst forecast dispersion

Security class action

$\begin{array}{cc}-0.035^{* *} & -0.208^{* *} \\ (-2.338) & (-2.116) \\ 0.002 & -0.010 \\ (0.712) & (-0.432) \\ -0.013 * * & 0.072 * \\ (-2.097) & (1.851)\end{array}$

$-1.013^{* * *}$

$-1.617 * * *$

$(-7.652)$

$(-4.215)$

$-1.724$

(5.003)

$(-1.324)$

$-0.013$

0.019

$(-0.584)$

$(0.118)$

$0.029 * *$

0.014

(2.220)

(0.134)

0.002

0.058

(0.120)

(0.627)

$-0.167$

0.182

$(-1.085)$

(0.145)

0.000

$(0.286)$

$-0.050$

$-0.007$

$(-0.843)$

$(-0.860)$

$-0.073$

$-0.001$

$(-0.196)$

$(-0.296)$

$-0.267 * * *$

$0.079^{* * *}$

(-4.028)

$0.244 * * *$

$-1.089^{* *}$

$(-2.466)$

$1.326^{* * *}$

(3.399) 
(Table 6 continued)

Stock return

Share turnover

Earnings surprise

Observations

Adjusted $\mathrm{R}^{2}$

Pseudo $\mathrm{R}^{2}$
$-0.326^{* *}$

$(-2.442)$

$0.517 * * *$

(4.952)

$-0.005 * *$

$(-2.032)$

3,828

3,355

0.45

0.21 


\section{Table 7. The Differential Effects of Classified Boards on the Cost of Debt Conditional on Market Uncertainty}

These models present the results of pooled OLS regressions for the differential effect of classified boards on the cost of debt, conditional on the degree of market uncertainty. The sample consists of S\&P 1,500 firms which do not have dual-class stocks and are not in the finance or utility industries from 2002 to 2007, and have public senior unsecured bonds. High volatility is a dummy variable that equals one if the equity volatility is above the median value in the sample, and zero otherwise. Small size is a dummy variable that equals one if the market value of the firm is smaller than or equal to the median value in the sample, and zero otherwise. High forecast dispersion is a dummy variable that equals one if the dispersion of analysts' earnings forecasts is above the median value in the sample, and zero otherwise. Rating dummies are generated from the Rate variable as defined in the Appendix. See the Appendix for the definitions of other variables. All models also include Fama-French 48-industry and year dummies, and a constant term, and are not reported to save space. Standard errors are adjusted for heteroskedasticity and clustered at the firm level. t-statistics are reported in parentheses. *, **, and *** indicate significance at the $10 \%, 5 \%$, and $1 \%$ levels, respectively.

\begin{tabular}{|c|c|c|c|c|c|c|}
\hline Dependent variable & $\begin{array}{c}(1) \\
\text { Spread }\end{array}$ & $\begin{array}{c}(2) \\
\text { Spread }\end{array}$ & $\begin{array}{c}\text { (3) } \\
\text { Spread }\end{array}$ & $\begin{array}{c}(4) \\
\text { Spread }\end{array}$ & $\begin{array}{c}(5) \\
\text { Spread }\end{array}$ & $\begin{array}{c}(6) \\
\text { Spread }\end{array}$ \\
\hline Sample & $\begin{array}{l}\text { High volatility } \\
=1\end{array}$ & $\begin{array}{c}\text { High volatility } \\
=0\end{array}$ & $\begin{array}{c}\text { Small size } \\
=1\end{array}$ & $\begin{array}{c}\text { Small size } \\
=0\end{array}$ & $\begin{array}{l}\text { High forecast } \\
\text { dispersion }=1\end{array}$ & $\begin{array}{l}\text { High forecast } \\
\text { dispersion }=0\end{array}$ \\
\hline $\begin{array}{l}\text { p-value for Chow } \\
\text { test }\end{array}$ & \multicolumn{2}{|c|}{$0.017 * *$} & \multicolumn{2}{|c|}{$0.041 * *$} & \multicolumn{2}{|c|}{$0.030 * *$} \\
\hline Cboard & $\begin{array}{c}-0.747 * * \\
(-2.342)\end{array}$ & $\begin{array}{c}0.138 \\
(0.761)\end{array}$ & $\begin{array}{c}-0.828 * * * \\
(-2.646)\end{array}$ & $\begin{array}{c}-0.077 \\
(-0.408)\end{array}$ & $\begin{array}{c}-0.852 * * * \\
(-2.742)\end{array}$ & $\begin{array}{c}-0.063 \\
(-0.326)\end{array}$ \\
\hline Net G-index & $\begin{array}{l}0.145^{*} \\
(1.812)\end{array}$ & $\begin{array}{c}-0.022 \\
(-0.569)\end{array}$ & $\begin{array}{c}0.093 \\
(1.339)\end{array}$ & $\begin{array}{c}0.011 \\
(0.267)\end{array}$ & $\begin{array}{c}0.059 \\
(0.947)\end{array}$ & $\begin{array}{c}0.005 \\
(0.103)\end{array}$ \\
\hline L-index & $\begin{array}{c}-0.457 * * * \\
(-3.146)\end{array}$ & $\begin{array}{c}0.038 \\
(0.466)\end{array}$ & $\begin{array}{l}-0.260^{*} \\
(-1.959)\end{array}$ & $\begin{array}{c}-0.075 \\
(-0.854)\end{array}$ & $\begin{array}{c}-0.111 \\
(-0.853)\end{array}$ & $\begin{array}{c}-0.007 \\
(-0.080)\end{array}$ \\
\hline Duration & $\begin{array}{c}-0.442 * * \\
(-2.388)\end{array}$ & $\begin{array}{l}-0.244^{*} \\
(-1.706)\end{array}$ & $\begin{array}{c}-0.455^{* * *} \\
(-2.602)\end{array}$ & $\begin{array}{c}-0.229 \\
(-1.480)\end{array}$ & $\begin{array}{c}-0.437 * * \\
(-2.181)\end{array}$ & $\begin{array}{l}-0.302 * * \\
(-2.233)\end{array}$ \\
\hline Convexity & $\begin{array}{c}0.001 \\
(0.078)\end{array}$ & $\begin{array}{c}0.002 \\
(0.305)\end{array}$ & $\begin{array}{c}0.002 \\
(0.245)\end{array}$ & $\begin{array}{c}0.000 \\
(0.062)\end{array}$ & $\begin{array}{c}0.003 \\
(0.386)\end{array}$ & $\begin{array}{c}0.002 \\
(0.410)\end{array}$ \\
\hline Bond age & $\begin{array}{c}0.303 * * * \\
(3.847)\end{array}$ & $\begin{array}{c}0.144 * * * \\
(3.724)\end{array}$ & $\begin{array}{c}0.224 * * * \\
(2.860)\end{array}$ & $\begin{array}{c}0.207 * * * \\
(4.806)\end{array}$ & $\begin{array}{c}0.246 * * * \\
(3.684)\end{array}$ & $\begin{array}{c}0.132 * * * \\
(3.092)\end{array}$ \\
\hline ROA & $\begin{array}{c}-5.252 * * \\
(-2.306)\end{array}$ & $\begin{array}{c}-0.368 \\
(-0.184)\end{array}$ & $\begin{array}{l}-4.861^{*} \\
(-1.730)\end{array}$ & $\begin{array}{l}-3.857^{*} \\
(-1.738)\end{array}$ & $\begin{array}{c}-5.739 * * \\
(-2.496)\end{array}$ & $\begin{array}{c}2.495 \\
(1.462)\end{array}$ \\
\hline Mkt size & $\begin{array}{c}-0.340 \\
(-1.633)\end{array}$ & $\begin{array}{c}-0.203 * * * \\
(-2.744)\end{array}$ & $\begin{array}{c}-0.696^{* *} \\
(-2.458)\end{array}$ & $\begin{array}{c}-0.155 \\
(-1.097)\end{array}$ & $\begin{array}{l}-0.379 * * \\
(-2.550)\end{array}$ & $\begin{array}{l}-0.215^{* *} \\
(-2.298)\end{array}$ \\
\hline Leverage & $\begin{array}{c}1.858 \\
(1.060)\end{array}$ & $\begin{array}{l}1.266^{* *} \\
(2.270)\end{array}$ & $\begin{array}{c}2.398 \\
(1.252)\end{array}$ & $\begin{array}{c}2.273 * * * \\
(3.112)\end{array}$ & $\begin{array}{c}1.833 \\
(1.119)\end{array}$ & $\begin{array}{c}2.472 * * * \\
(3.400)\end{array}$ \\
\hline Volatility & $\begin{array}{c}3.894 \\
(0.743)\end{array}$ & $\begin{array}{c}1.819 \\
(0.216)\end{array}$ & $\begin{array}{l}10.090^{*} \\
(1.961)\end{array}$ & $\begin{array}{c}-2.318 \\
(-0.537)\end{array}$ & $\begin{array}{l}9.133^{*} \\
(1.688)\end{array}$ & $\begin{array}{c}1.708 \\
(0.455)\end{array}$ \\
\hline $\mathrm{Mb}$ & $\begin{array}{c}-0.491 * * \\
(-2.128)\end{array}$ & $\begin{array}{c}-0.153 \\
(-1.578)\end{array}$ & $\begin{array}{l}-0.543^{*} \\
(-1.925)\end{array}$ & $\begin{array}{c}-0.039 \\
(-0.413)\end{array}$ & $\begin{array}{c}-0.275 \\
(-0.808)\end{array}$ & $\begin{array}{c}-0.275 * * * \\
(-3.024)\end{array}$ \\
\hline Sub debt & $\begin{array}{l}-0.921 * * \\
(-2.399)\end{array}$ & $\begin{array}{c}0.110 \\
(0.652)\end{array}$ & $\begin{array}{c}-1.120 * * * \\
(-3.166)\end{array}$ & $\begin{array}{l}-0.150 \\
(-0.654)\end{array}$ & $\begin{array}{c}-0.530 \\
(-1.570)\end{array}$ & $\begin{array}{c}-0.416^{* *} \\
(-2.233)\end{array}$ \\
\hline CEO options & $\begin{array}{c}-0.244 \\
(-0.458)\end{array}$ & $\begin{array}{l}-0.160 \\
(-0.512)\end{array}$ & $\begin{array}{c}-0.873 \\
(-1.496)\end{array}$ & $\begin{array}{c}0.268 \\
(0.949)\end{array}$ & $\begin{array}{c}-0.809 \\
(-1.179)\end{array}$ & $\begin{array}{c}-0.186 \\
(-0.685)\end{array}$ \\
\hline
\end{tabular}


(Table 7 continued)

\begin{tabular}{lcccccc}
\hline CEO shares & 1.511 & 1.492 & -1.595 & $13.873^{*}$ & 2.785 & -0.127 \\
& $(0.333)$ & $(0.685)$ & $(-0.423)$ & $(1.829)$ & $(0.446)$ & $(-0.054)$ \\
Indep director & 0.278 & $0.785^{*}$ & 0.984 & 0.282 & 0.012 & $0.861^{* *}$ \\
& $(0.248)$ & $(1.680)$ & $(0.892)$ & $(0.463)$ & $(0.013)$ & $(2.058)$ \\
Board size & 0.020 & -0.029 & -0.046 & 0.064 & 0.017 & 0.005 \\
& $(0.313)$ & $(-0.763)$ & $(-0.732)$ & $(1.467)$ & $(0.324)$ & $(0.119)$ \\
Inst shares & $-4.159^{* *}$ & -0.436 & $-3.904^{* *}$ & $1.613^{*}$ & $-4.099^{* *}$ & -0.345 \\
& $(-2.559)$ & $(-0.483)$ & $(-2.561)$ & $(1.663)$ & $(-2.305)$ & $(-0.353)$ \\
Block shares & $4.553^{* * *}$ & $-1.908^{*}$ & $3.104^{* *}$ & -0.613 & $2.448^{*}$ & -0.644 \\
& $(3.015)$ & $(-1.896)$ & $(2.289)$ & $(-0.589)$ & $(1.700)$ & $(-0.669)$ \\
Rate2 & $-8.419^{*}$ & 0.603 & $-8.324^{*}$ & & $-5.283^{* * *}$ & 0.000 \\
& $(-1.882)$ & $(0.892)$ & $(-1.738)$ & & $(-4.819)$ & $()$. \\
Rate3 & $-8.604^{*}$ & 0.418 & $-8.001^{*}$ & -1.936 & $-5.384^{* * *}$ & $0.675^{*}$ \\
& $(-1.914)$ & $(0.786)$ & $(-1.671)$ & $(-1.264)$ & $(-4.342)$ & $(1.837)$ \\
Rate4 & $-9.356^{* *}$ & 0.026 & $-8.802^{*}$ & -2.335 & $-6.059^{* * *}$ & -0.400 \\
& $(-2.049)$ & $(0.053)$ & $(-1.809)$ & $(-1.527)$ & $(-4.973)$ & $(-1.196)$ \\
Rate5 & $-9.402^{* *}$ & -0.264 & $-9.502^{*}$ & -2.241 & $-6.301^{* * *}$ & -0.402 \\
& $(-2.043)$ & $(-0.638)$ & $(-1.954)$ & $(-1.426)$ & $(-4.869)$ & $(-0.931)$ \\
Rate6 & $-9.485^{* *}$ & 0.161 & -7.779 & -1.721 & $-5.781^{* * *}$ & 0.090 \\
& $(-2.051)$ & $(0.443)$ & $(-1.598)$ & $(-0.996)$ & $(-3.748)$ & $(0.151)$ \\
Rate7 & & & & -1.789 & & -0.026 \\
& & & & $(-1.042)$ & & $(-0.038)$ \\
Observations & 733 & 734 & 734 & 733 & 695 & 694 \\
Adjusted R ${ }^{2}$ & 0.51 & 0.18 & 0.48 & 0.21 & 0.45 & 0.22 \\
\hline
\end{tabular}




\section{Table 8. The Differential Impact of Classified Boards on Firm Performance}

These models present the results of pooled OLS regressions for the differential effect of classified boards on Tobin's $\mathrm{Q}$, conditional on the expected divergence of interests between shareholders and bondholders and the degree of market uncertainty. The samples consist of S\&P 1,500 non-dual-class, non-finance, and non-utility firms from 2002 to 2007. High leverage is a dummy variable that equals one if the firm's leverage is greater than the median value in the sample, and zero otherwise. SPC is a dummy variable that equals one if the firm's SP rate is speculative-grade (below BBB-), and zero otherwise. High volatility is a dummy variable that equals one if the equity volatility is above the median value in the sample, and zero otherwise. Small size is a dummy variable that equals one if the market value of the firm is smaller than or equal to the median value in the sample, and zero otherwise. High forecast dispersion is a dummy variable that equals one if the dispersion of analysts' earnings forecasts is above the median value in the sample, and zero otherwise. See the Appendix for the definitions of all other variables. All models include Fama-French 48-industry and year dummies, and a constant term, and are not reported to save space. Standard errors are adjusted for heteroskedasticity and clustered at the firm level. t-statistics are reported in parentheses. $*, * *$, and $* * *$ indicate significance at the $10 \%, 5 \%$, and $1 \%$ levels, respectively.

\begin{tabular}{|c|c|c|c|c|c|c|c|}
\hline Dependent variable & $\begin{array}{c}(1) \\
Q\end{array}$ & $\begin{array}{c}(2) \\
Q\end{array}$ & $\begin{array}{c}(3) \\
Q\end{array}$ & $\begin{array}{c}(4) \\
Q\end{array}$ & $\begin{array}{c}(5) \\
Q\end{array}$ & $\begin{array}{c}(6) \\
Q\end{array}$ & $\begin{array}{c}(7) \\
Q\end{array}$ \\
\hline Cboard & $\begin{array}{c}-0.145^{* *} * \\
(-2.290)\end{array}$ & $\begin{array}{c}-0.259 * * * \\
(-2.758)\end{array}$ & $\begin{array}{c}-0.169 * * \\
(-2.091)\end{array}$ & $\begin{array}{c}-0.153 * * \\
(-2.067)\end{array}$ & $\begin{array}{c}-0.143 \\
(-1.629)\end{array}$ & $\begin{array}{c}-0.222 * * * \\
(-2.615)\end{array}$ & $\begin{array}{c}-0.185^{* *} \\
(-1.978)\end{array}$ \\
\hline High leverage $*$ Cboard & & $\begin{array}{c}0.224 * * \\
(2.254)\end{array}$ & & & & & \\
\hline High leverage & & $\begin{array}{c}-0.437 * * * \\
(-4.401)\end{array}$ & & $\begin{array}{c}-0.337 * * * \\
(-4.523)\end{array}$ & & & \\
\hline SPC * Cboard & & & $\begin{array}{c}0.303 * * * \\
(2.805)\end{array}$ & & & & \\
\hline SPC & & & $\begin{array}{c}-0.488 * * * \\
(-4.867)\end{array}$ & $\begin{array}{c}-0.336 * * * \\
(-3.153)\end{array}$ & & & \\
\hline High leverage $*$ SPC $*$ & & & & $0.299 * * *$ & & & \\
\hline Cboard & & & & $(2.983)$ & & & \\
\hline High leverage $*$ SPC & & & & $\begin{array}{c}-0.144 \\
(-1.180)\end{array}$ & & & \\
\hline High volatility * & & & & & -0.007 & & \\
\hline Cboard & & & & & $(-0.066)$ & & \\
\hline High volatility & & & & & $\begin{array}{c}-0.026 \\
(-0.268)\end{array}$ & & \\
\hline Small size $*$ Cboard & & & & & & $\begin{array}{c}0.181^{*} \\
(1.854)\end{array}$ & \\
\hline Small size & & & & & & $\begin{array}{c}-1.145^{* * *} \\
(-11.313)\end{array}$ & \\
\hline $\begin{array}{l}\text { High forecast } \\
\text { dispersion } * \text { Cboard } \\
\text { High forecast } \\
\text { dispersion }\end{array}$ & & & & & & & $\begin{array}{c}0.107 \\
(1.123) \\
-0.420 * * * \\
(-5.042)\end{array}$ \\
\hline Net G-index & $\begin{array}{c}-0.009 \\
(-0.773)\end{array}$ & $\begin{array}{c}-0.008 \\
(-0.701)\end{array}$ & $\begin{array}{l}-0.022^{*} \\
(-1.945)\end{array}$ & $\begin{array}{l}-0.022 * \\
(-1.960)\end{array}$ & $\begin{array}{c}-0.009 \\
(-0.813)\end{array}$ & $\begin{array}{c}-0.015 \\
(-1.386)\end{array}$ & $\begin{array}{l}-0.019 * \\
(-1.713)\end{array}$ \\
\hline Board size & $\begin{array}{l}-0.023^{*} \\
(-1.676)\end{array}$ & $\begin{array}{c}-0.021 \\
(-1.540)\end{array}$ & $\begin{array}{c}-0.016 \\
(-1.126)\end{array}$ & $\begin{array}{c}-0.010 \\
(-0.756)\end{array}$ & $\begin{array}{l}-0.024^{*} \\
(-1.701)\end{array}$ & $\begin{array}{c}-0.021 \\
(-1.579)\end{array}$ & $\begin{array}{c}-0.017 \\
(-1.228)\end{array}$ \\
\hline
\end{tabular}


(Table 8 continued)

\begin{tabular}{|c|c|c|c|c|c|c|c|}
\hline Indep director & $\begin{array}{c}0.246 \\
(1.391)\end{array}$ & $\begin{array}{c}0.253 \\
(1.432)\end{array}$ & $\begin{array}{c}0.084 \\
(0.398)\end{array}$ & $\begin{array}{c}0.097 \\
(0.465)\end{array}$ & $\begin{array}{c}0.243 \\
(1.372)\end{array}$ & $\begin{array}{c}0.256 \\
(1.557)\end{array}$ & $\begin{array}{c}0.154 \\
(0.851)\end{array}$ \\
\hline \multirow[t]{2}{*}{ CEO senior } & 0.036 & 0.037 & -0.008 & -0.003 & 0.036 & 0.076 & 0.037 \\
\hline & $(0.374)$ & $(0.382)$ & $(-0.092)$ & $(-0.035)$ & $(0.373)$ & $(0.855)$ & $(0.376)$ \\
\hline \multirow[t]{2}{*}{ CEO sole insider } & $-0.139 * * *$ & $-0.137 * * *$ & $-0.118 * *$ & $-0.112 * *$ & $-0.139 * * *$ & $-0.133 * * *$ & $-0.103^{* *}$ \\
\hline & $(-2.705)$ & $(-2.701)$ & $(-2.169)$ & $(-2.067)$ & $(-2.721)$ & $(-2.783)$ & $(-2.062)$ \\
\hline \multirow[t]{2}{*}{ CEO chair } & -0.040 & -0.035 & -0.049 & -0.034 & -0.040 & -0.053 & -0.041 \\
\hline & $(-0.934)$ & $(-0.822)$ & $(-1.235)$ & $(-0.881)$ & $(-0.922)$ & $(-1.330)$ & $(-0.959)$ \\
\hline \multirow[t]{2}{*}{ CEO shares } & -0.618 & -0.641 & 1.254 & 1.252 & -0.633 & -0.057 & -0.417 \\
\hline & $(-0.876)$ & $(-0.918)$ & $(0.986)$ & $(1.000)$ & $(-0.900)$ & $(-0.086)$ & $(-0.579)$ \\
\hline \multirow[t]{2}{*}{ CEO tenure } & 0.003 & 0.003 & -0.002 & -0.001 & 0.003 & -0.001 & 0.003 \\
\hline & $(0.625)$ & $(0.596)$ & $(-0.284)$ & $(-0.268)$ & $(0.641)$ & $(-0.113)$ & $(0.576)$ \\
\hline \multirow[t]{2}{*}{$\mathrm{ROA}$} & $2.963 * * *$ & $2.976 * * *$ & $3.326 * * *$ & $3.323 * * *$ & $2.946 * * *$ & $2.543 * * *$ & $3.177 * * *$ \\
\hline & $(6.155)$ & $(6.273)$ & $(6.388)$ & $(6.608)$ & $(6.096)$ & $(6.090)$ & $(7.291)$ \\
\hline \multirow[t]{2}{*}{ Book size } & -0.002 & -0.001 & -0.053 & $-0.057^{*}$ & -0.004 & $-0.261 * * *$ & -0.011 \\
\hline & $(-0.068)$ & $(-0.026)$ & $(-1.592)$ & $(-1.752)$ & $(-0.125)$ & $(-7.389)$ & $(-0.384)$ \\
\hline \multirow[t]{2}{*}{ Capexp } & $3.241 * * *$ & $3.202 * * *$ & $2.318 * * *$ & $2.265^{* * * *}$ & $3.238 * * *$ & $2.675 * * *$ & $2.868 * * *$ \\
\hline & $(4.380)$ & $(4.390)$ & $(3.417)$ & $(3.434)$ & $(4.376)$ & $(4.027)$ & (3.994) \\
\hline \multirow[t]{2}{*}{ Leverage } & $-0.834 * * *$ & -0.113 & -0.377 & 0.312 & $-0.835 * * *$ & $-0.550 * *$ & $-1.037 * * *$ \\
\hline & $(-3.560)$ & $(-0.327)$ & $(-1.510)$ & $(1.057)$ & $(-3.568)$ & $(-2.579)$ & $(-4.504)$ \\
\hline \multirow[t]{2}{*}{ Firm age } & -0.044 & -0.043 & -0.000 & 0.008 & -0.047 & -0.008 & -0.049 \\
\hline & $(-0.956)$ & $(-0.939)$ & $(-0.008)$ & $(0.189)$ & $(-1.018)$ & $(-0.199)$ & $(-1.110)$ \\
\hline \multirow[t]{2}{*}{ Segments } & -0.063 & -0.063 & 0.017 & 0.005 & -0.063 & -0.040 & -0.055 \\
\hline & $(-1.323)$ & $(-1.335)$ & $(0.361)$ & $(0.106)$ & $(-1.319)$ & $(-0.941)$ & $(-1.161)$ \\
\hline Observations & 4,232 & 4,232 & 2,392 & 2,392 & 4,232 & 4,232 & 3,868 \\
\hline Adjusted $\mathrm{R}^{2}$ & 0.30 & 0.31 & 0.41 & 0.42 & 0.30 & 0.40 & 0.36 \\
\hline
\end{tabular}




\section{Table 9. Endogeneity Tests for Classified Boards and the Cost of Debt}

These models check the robustness of the results of classified boards on the cost of debt in view of the concern for endogeneity. The sample for Models 1-3 consists of the S\&P 1,500 firms which do not have dual-class stocks and are not in the finance or utility industries, and have public senior unsecured bonds from 2002 to 2007 , and have not changed their board classification status since 1990. The sample for Model 4 consists of the S\&P 1,500 non-dualclass, non-finance, and non-utility firms that either declassified or classified their boards between 2002 and 2007. Models 1-3 use pooled OLS model. Model 4 uses first-differences model. $\Delta$ denotes the change of a variable over previous year. Rating dummies are generated from the Rate variable as defined in the Appendix. See the Appendix for the definitions of other variables. All models include year dummies and a constant term. Models 1-3 also include Fama-French 48-industry dummies. Model 4 also includes Fama-French 12-industry dummies. Coefficients for these variables are not reported to save space. Standard errors are adjusted for heteroskedasticity and clustered at the firm level. t-statistics are reported in parentheses. $*$, **, and $* * *$ indicate significance at the $10 \%, 5 \%$, and $1 \%$ levels, respectively.

\begin{tabular}{|c|c|c|c|c|}
\hline Dependent variable & $\begin{array}{c}(1) \\
\text { Spread }\end{array}$ & $\begin{array}{c}(2) \\
\text { Spread } \\
\end{array}$ & $\begin{array}{c}(3) \\
\text { Spread } \\
\end{array}$ & $\begin{array}{c}(4) \\
\Delta \text { Spread } \\
\end{array}$ \\
\hline Cboard at 1990 & $\begin{array}{l}-0.493 * \\
(-1.855)\end{array}$ & $\begin{array}{l}-0.469 * \\
(-1.842)\end{array}$ & $\begin{array}{l}-0.416^{*} \\
(-1.849)\end{array}$ & \\
\hline$\Delta$ Cboard & & & & $\begin{array}{c}-3.039 * * \\
(-2.093)\end{array}$ \\
\hline Net G-index & & $\begin{array}{c}-0.023 \\
(-0.445)\end{array}$ & $\begin{array}{c}0.045 \\
(0.892)\end{array}$ & \\
\hline L-index & & $\begin{array}{c}-0.069 \\
(-0.554)\end{array}$ & $\begin{array}{c}-0.102 \\
(-0.816)\end{array}$ & \\
\hline$\Delta$ Net G-index & & & & $\begin{array}{c}0.672 \\
(1.372)\end{array}$ \\
\hline$\Delta \mathrm{L}$-index & & & & $\begin{array}{c}-3.664 * * * \\
(-3.084)\end{array}$ \\
\hline Duration & $\begin{array}{c}-0.744 * * * \\
(-4.582)\end{array}$ & $\begin{array}{c}-0.750 * * * \\
(-4.464)\end{array}$ & $\begin{array}{c}-0.760 * * * \\
(-4.603)\end{array}$ & \\
\hline Convexity & $\begin{array}{c}0.021 * * * \\
(3.021)\end{array}$ & $\begin{array}{c}0.021 * * * \\
(2.970)\end{array}$ & $\begin{array}{c}0.021 * * * \\
(3.049)\end{array}$ & \\
\hline Bond age & $\begin{array}{c}0.227 * * * \\
(5.254)\end{array}$ & $\begin{array}{c}0.225 * * * \\
(5.224)\end{array}$ & $\begin{array}{c}0.229 * * * \\
(5.317)\end{array}$ & \\
\hline ROA & $\begin{array}{l}-2.766^{*} \\
(-1.707)\end{array}$ & $\begin{array}{l}-2.796^{*} \\
(-1.746)\end{array}$ & $\begin{array}{c}-1.668 \\
(-1.090)\end{array}$ & \\
\hline Mkt size & $\begin{array}{c}-0.386^{* * *} \\
(-3.250)\end{array}$ & $\begin{array}{c}-0.405 * * * \\
(-3.254)\end{array}$ & $\begin{array}{c}-0.183 \\
(-1.257)\end{array}$ & \\
\hline Leverage & $\begin{array}{c}3.501 * * * \\
(3.425)\end{array}$ & $\begin{array}{c}3.493 * * * \\
(3.405)\end{array}$ & $\begin{array}{c}2.713 * * * \\
(2.837)\end{array}$ & \\
\hline Volatility & $\begin{array}{c}10.606^{* *} \\
(2.467)\end{array}$ & $\begin{array}{c}10.309 * * \\
(2.429)\end{array}$ & $\begin{array}{c}-0.782 \\
(-0.162)\end{array}$ & \\
\hline $\mathrm{Mb}$ & $\begin{array}{c}-0.163 \\
(-1.009)\end{array}$ & $\begin{array}{c}-0.157 \\
(-0.974)\end{array}$ & $\begin{array}{c}-0.189 \\
(-1.554)\end{array}$ & \\
\hline Sub debt & $\begin{array}{c}0.093 \\
(0.275)\end{array}$ & $\begin{array}{c}0.093 \\
(0.273)\end{array}$ & $\begin{array}{c}-0.166 \\
(-0.493)\end{array}$ & \\
\hline Rate3 & & & $\begin{array}{c}-1.752 \\
(-1.448)\end{array}$ & \\
\hline
\end{tabular}

(continued) 
(Table 9 continued)

\begin{tabular}{|c|c|c|c|c|}
\hline Rate4 & & & $\begin{array}{c}-3.011^{* *} \\
(-2.519)\end{array}$ & \\
\hline Rate5 & & & $\begin{array}{c}-3.231 * * \\
(-2.576)\end{array}$ & \\
\hline Rate6 & & & $\begin{array}{c}-3.100 * * \\
(-2.168)\end{array}$ & \\
\hline Rate7 & & & $\begin{array}{c}-2.275 \\
(-1.467)\end{array}$ & \\
\hline$\Delta$ Duration & & & & $\begin{array}{c}-0.367 \\
(-0.289)\end{array}$ \\
\hline$\Delta$ Convexity & & & & $\begin{array}{c}0.003 \\
(0.043)\end{array}$ \\
\hline$\triangle \mathrm{ROA}$ & & & & $\begin{array}{c}-0.748 \\
(-0.095)\end{array}$ \\
\hline$\Delta \mathrm{Mkt}$ size & & & & $\begin{array}{c}1.915 \\
(0.612)\end{array}$ \\
\hline$\Delta$ Leverage & & & & $\begin{array}{l}16.275 \\
(1.104)\end{array}$ \\
\hline$\Delta$ Volatility & & & & $\begin{array}{l}15.876 \\
(1.282)\end{array}$ \\
\hline$\Delta \mathrm{Mb}$ & & & & $\begin{array}{c}0.320 \\
(0.214)\end{array}$ \\
\hline Observations & 1,009 & 1,009 & 1,009 & 35 \\
\hline Adjusted $\mathrm{R}^{2}$ & 0.31 & 0.31 & 0.34 & 0.39 \\
\hline
\end{tabular}




\section{Table 10. Sample Selection Bias and Bond Covenants}

These models test the robustness of the results on the effect of classified boards on the cost of debt. Model 1 uses Heckman's two-step sample selection model. Only the second step results are reported. Model 2 uses pooled OLS model. The sample for Model 1 (second step of the Heckman two-step sample selection model) consists of the S\&P 1,500 firms which do not have dual-class stocks and are not in the finance or utility industries from 2002 to 2007. The sample for Model 2 consists of the S\&P 1,500 firms which do not have dual-class stocks and are not in the finance or utility industries, and have public senior unsecured bonds between 2002 and 2007. Investment (financing, dividend, event) restrictions is the weighted average of the dummy variables indicating whether an issue has one of the investment (financing, dividend, event) covenants, and across different issues of the firm in a given year, where the weight on an issue is the issue size as a percentage of the aggregate issue sizes of the firm in a given year. The detailed categorization of different covenants follows Smith and Warner (1979) and Chava, Kumar, and Warga (2010). See the Appendix for the definitions of other variables. Both models also include the control variables as in Model 5 of Table 2, and are not reported to save space. Standard errors are adjusted for heteroskedasticity and clustered at the firm level. t-statistics are reported in parentheses. * **, and *** indicate significance at the $10 \%$, $5 \%$, and $1 \%$ levels, respectively.

\begin{tabular}{lcc}
\hline Dependent variable & $(1)$ & $(2)$ \\
Cboard & Spread & Spread \\
& & \\
Investment restrictions & $-0.425^{* * *}$ & $-0.364^{*}$ \\
& $(-2.974)$ & $(-1.840)$ \\
Financing restrictions & & $-1.092^{*}$ \\
& & $(-1.662)$ \\
Dividend restrictions & & 0.618 \\
& & $(1.233)$ \\
Event restrictions & & 0.107 \\
& & $(0.367)$ \\
Net G-index & & -0.141 \\
& $0.085^{* *}$ & $(-0.656)$ \\
L-index & $(2.335)$ & 0.045 \\
& $-0.217^{* * *}$ & $(0.882)$ \\
Observations & $(-2.714)$ & -0.107 \\
Adjusted $\mathrm{R}^{2}$ & 6,580 & $(-1.100)$ \\
Wald Chi ${ }^{2}$ & & 1,091 \\
\end{tabular}

